\title{
Audit Leadership Diversity and Audit Quality
}

\author{
Ling Lei Lisic \\ Pamplin College of Business \\ Virginia Polytechnic Institute and State University (Virginia Tech) \\ llisic@vt.edu \\ Timothy A. Seidel* \\ BYU Marriott School of Business \\ Brigham Young University \\ timseidel@,byu.edu \\ J. Mike Truelson \\ Pamplin College of Business \\ Virginia Polytechnic Institute and State University (Virginia Tech) \\ jtruel1@vt.edu \\ Aleksandra "Ally" B. Zimmerman \\ College of Business \\ Florida State University \\ azimmerman@business.fsu.edu
}

October 2020

*Corresponding Author

Acknowledgements: We are grateful for helpful comments and suggestions from Andrew Acito, Sudip Bhattacharjee, Ken Bills, Brant Christensen, Matthew Cobabe, Matthew Erickson, Michelle Harding, Scott Johnson, Michelle Lowry, Miguel Minutti-Meza, Jeff Pittman, Sarah Stein, Marshall Vance, Kim Walker, Devin Williams, and workshop participants at Virginia Tech. Ling Lisic gratefully acknowledges financial support from the L. Mahlon Harrell Junior Faculty Fellowship at Virginia Tech, and Timothy Seidel gratefully acknowledges financial support from the Glen D. Ardis Fellowship at Brigham Young University. 


\title{
Audit Leadership Diversity and Audit Quality
}

\begin{abstract}
We examine whether a culture emphasizing diversity in accounting firms, as embodied by the diversity of local offices' audit leaders, influences audit quality. An organizational culture that emphasizes diverse perspectives and experiences can have a permeating influence on the execution of all local audits, particularly with respect to judgment and decision-making. We develop a composite measure of audit office partner diversity by capturing and combining variations among the following audit office partner characteristics: gender, age, ethnicity, education, client base, and expertise. Our results indicate that greater diversity in audit office partners is associated with higher audit quality among office clientele, incremental to characteristics of the client, the geographic area, the audit office, and the engagement partner, including engagement partner, client, and MSA fixed effects. These findings underscore the importance of an audit office culture that values diversity and provide important practical implications.
\end{abstract}

Keywords: diversity, leadership, audit quality, audit offices, audit partners, audit fees

JEL Classifications: M41, M42 


\section{Audit Leadership Diversity and Audit Quality}

"Deloitte is diversity...In the evolution of leadership, diversity is not defined just by race or gender. It also encompasses the whole human experience, age, culture, education, personality, skills and life experiences."

"We believe diversity is good for business. Diversity of background, diversity of experience, diversity of perspective. That's the KPMG difference. We encourage you to succeed, whoever you

are... whatever your gender, ethnicity, age, disability, religion or sexual orientation, you can succeed at KPMG."

\section{Introduction}

The accounting profession has long been criticized for a lack of diversity, particularly within the leadership positions of the largest accounting firms. ${ }^{3}$ In recent years, accounting firms have been making concerted efforts to broaden their recruitment efforts, foster inclusive work environments, and retain and promote professionals with diverse backgrounds. ${ }^{4}$ Because leadership represents the embodiment of firm culture, which can have a permeating influence on employee behavior (Bamber et al. 2010; Dyreng et al. 2010), a more diverse set of leaders should instill a sense of the importance of diverse backgrounds, perspectives, and collective decisionmaking within an organization. As such, the resulting influence of a culture that embraces diversity and inclusivity should be of particular interest to a professional services firm where audits are conducted by engagement teams and require a significant amount of coordination and collaboration. In this study, we examine whether a culture of diversity and inclusion as embodied by the diversity of the local leaders of the audit practice influences audit quality. ${ }^{5}$

\footnotetext{
${ }^{1}$ https://www2.deloitte.com/global/en/pages/about-deloitte/topics/global-diversity-deloitte-is-diversity.html

2 https://home.kpmg/uk/en/home/about/people/inclusion-diversity.html

${ }^{3}$ See https://www.accountingtoday.com/opinion/accounting-firms-face-up-to-diversity-challenges.

${ }^{4}$ For example, three of the Big Four accounting firms have recently promoted women to lead their firms' U.S. operations and all four firms highlight their commitment to diversity and inclusion in their respective annual transparency/audit quality reports (Deloitte 2019; EY 2019a; KPMG 2019; PwC 2019).

${ }^{5} \mathrm{We}$ argue that a culture of diversity of espoused by local leaders permeates all engagements increasing local audit quality on average at the margin, regardless of any engagement-team-specific diversity.
} 
Given that large "audit firms operate through a network of semi-autonomous practice offices" that "contract with clients, administer audit engagements, and issue audit reports signed on the local office letterhead" (Francis and Yu 2009, 1523), we operationalize the diversity of audit practice leaders at the office level. Audit partners within an office often lead office client engagement teams, assess and reward performance of professionals within the office, and have significant influence over retention and promotion decisions. Prior research suggests that individuals within an organization pay particular attention to the actions and attitudes of leaders more directly responsible for supervision and promotion (Kelly and Earley 2009; Schein 2010). Thus, given the semi-autonomous nature of audit offices, we focus on the culture and tone at the audit office level as exhibited by the diversity among office audit leaders.

The impact of a culture of diversity and inclusion on audit quality is not necessarily clear. On the one hand, a culture that embraces and values diversity can lead to creative thinking and better decision-making. Many argue that "a diverse mix of voices leads to better discussions, decisions, and outcomes for everyone" (Pichai \& Google Inc. 2016). Tim Ryan, PwC's U.S. Senior Partner, states "when you include a diversity of minds in the decision-making process, you inevitably have a better and stronger result because the environment in the room becomes open. You start talking with people, rather than talking at them. ${ }^{, 6}$ A culture that values diversity can reduce the potential for social conformity (i.e., group think), where only a limited set of alternatives are considered when evaluating an issue (Cameran, Ditillo, and Pettinicchio 2018). It can encourage professionals to share ideas and perspectives and reduce the tendency of certain minority group members to feel isolated (Gigone and Hastie 1993), thereby facilitating better discussions and decisions and moderating extreme alternatives (Kent and McGrath 1969;

\footnotetext{
${ }^{6}$ https://www.pwc.com/us/en/about-us/diversity/pwc-diversity-commitment.html.
} 
Kirchmeyer and Cohen 1992; Watson et al. 1993; Bernile et al. 2018). Additionally, such a culture likely fosters a more inclusive workplace environment, which can lead to increased retention and productivity. This is especially important for audit firms, which often experience high levels of employee turnover. ${ }^{7}$ Greater team continuity and productivity can preserve client-specific knowledge gained over time and lead to improvements in the effectiveness and efficiency of the audit. In sum, a culture that embraces diversity and inclusion can lead to higher quality audit outcomes.

On the other hand, not all research suggests that diversity of thought and experience that stems from a more diverse group yields positive outcomes. Several studies across various disciplines find evidence of greater dysfunctionality and turnover among more diverse groups (Linville and Jones 1980; O'Reilly, Snyder and Boothe 1993; Pelled 1996). In the corporate governance literature, Anderson, Reeb, Upadhyay, and Zhao (2011) provide no evidence that greater board heterogeneity improves board efficacy. In the auditing setting, it is certainly possible that increased cognitive similarity that results from a more homogenous set of audit professionals facilitates interaction and collaboration. Greater diversity could lead to inefficiencies, less collaboration, or reduced consensus agreement on issues of audit importance. To the extent a culture that encourages greater diversity leads auditors to work more autonomously or in a more dysfunctional manner, audit quality could suffer. As such, the impact of culture that embraces diversity on audit quality is an empirical question.

We proxy for a diverse and inclusive culture at the audit office with the diversity of the office's audit partners. We develop a broad, multi-dimensional measure of audit partner diversity

\footnotetext{
${ }^{7}$ See page xxiv of The Inside Public Accounting National Benchmarking Report at http://insidepublicaccounting.com/wp-content/uploads/2015/09/INSIDE-Public-Accounting_Executive-Summary2015-FINAL.pdf.
} 
that should reflect diversity in thought, experience, and perspective as advocated by the accounting profession. Specifically, we create a composite measure of office leadership diversity based on the variation in six characteristics of office audit partners: gender, age, ethnicity, education, client base, and expertise. ${ }^{8}$ To construct this measure, we obtain engagement partner identities from the Public Company Accounting Oversight Board (PCAOB) Form AP disclosure for all issuer audit reports issued on or after January 31, 2017 and link them to various demographic characteristics following methodologies used in prior research as well as professional networking website profiles and other websites. We limit our examination to clients in audit offices of the eight largest public accounting firms to help minimize systematic differences in the size, composition, and quality control structures of the audit firms included in our sample. ${ }^{9}$ We then examine the association between the level of diversity of audit partners in an office and the quality of the offices' audits. We proxy for audit quality using measures that capture inputs into, as well as observable outcome measures of, the audit process (DeFond and Zhang 2014). Specifically, we use material misstatements identified through subsequent restatements, discretionary accruals, and accounting conservatism to proxy for the quality of audited reports and audit fees to proxy for audit effort.

Our analyses reveal that greater audit partner diversity within U.S. audit firm offices has an incremental effect on the quality of audits produced by those offices beyond other office-level characteristics such as office size and industry expertise, and a host of other local area, engagement-level and audit firm-level characteristics. In additional analyses, we find that this

\footnotetext{
${ }^{8}$ We recognize that diversity in audit partner expertise and age may less representative of the diversity in expertise and age of other audit office professionals. Public accounting firms tend to recruit staff directly from universities and follow a structured promotion process. Thus, the expertise and age of non-partner professionals within audit offices may be less diverse than among the partner group. In additional analyses described in Section IV, we limit our audit office leadership diversity measure to partner gender, ethnicity, and education and find consistent inferences.

${ }^{9}$ The eight largest public accounting firms include PwC, EY, Deloitte, KPMG, Grant Thornton, BDO, RSM, and Crowe.
} 
effect is also incremental to individual engagement partner characteristics or audit partner fixed effects. Specifically, we find that clients in audit offices with more audit office partner diversity exhibit a lower likelihood of misstatement, lower signed and unsigned discretionary accruals, more timely loss recognition, and higher audit fees. These results are consistent with the proposition that local leadership diversity positively influences audit quality, consistent with claims made by accounting firms that a culture of diversity fosters audit quality (e.g., EY 2019b).

In additional analyses, we 1) decompose our diversity measure into its separate components and examine the association between each individual component and our audit quality proxies, and 2) capture several variations of our audit office leadership diversity measure by removing individual diversity components from our measure one at a time. From these analyses, it does not appear that any individual diversity component is driving the main results. Rather, it is the aggregation of the various components that appears to influence audit quality. Additionally, we perform analyses to alleviate the concern that correlated omitted variables such as the number of partners within an office are driving the observed results. Importantly, our results are robust to controlling for individual engagement partner fixed effects or individual engagement partner characteristics. The results of these analyses help strengthen the inferences from the main analyses that greater audit partner diversity in an audit office is associated with higher quality audits.

Our study focuses on an issue that is very important in audit practice. Given the integral role that firm culture and tone plays in audit firms' overall system of quality control, regulators often focus on the tone at the top exhibited by audit firm leaders when performing periodic firm inspections (PCAOB 2015; IFAC 2007; CAQ 2010; COSO 2013). Additionally, accounting firms have invested significant resources in diversity initiatives related to recruiting, retention, and 
promotion. Our findings provide empirical evidence regarding these investments that should be of interest to accounting firms and regulators responsible for overseeing and promoting audit quality.

These findings contribute to the growing evidence on the importance of firm culture and tone at the top to firm performance and outcomes (Bamber et al. 2010; Dyreng et al. 2010; Skaife et al. 2013; Brown et al. 2020) and to the growing literature examining the influence of partnerlevel characteristics on audit quality (see Lennox and Wu 2018 for a review). Prior research finds that certain isolated partner characteristics (such as gender or expertise) are associated with audit pricing and quality (e.g., Hardies, Breesch, and Branson 2015; Chi, Myers, Omer, and Xie 2017; Lee, Nagy and Zimmerman 2019). Our study contributes to this stream of research by documenting that the office-wide culture of diversity and inclusion, as proxied by a multi-dimensional measure of audit partner diversity within an audit office has a significant association with audit quality, incremental to individual engagement partner characteristics and fixed effects.

The remainder of the paper is organized as follows. Section 2 reviews prior literature and provides motivation for our hypothesis. Section 3 outlines our research design. Section 4 describes the sample and empirical results. Section 5 covers the supplemental and sensitivity analyses, while Section 6 concludes.

\section{Literature review and hypothesis development}

\section{Audit firm diversity initiatives}

All of the major accounting firms advocate the importance of diversity in publications, on their websites, and in their recruiting materials. For example, KPMG issued a 2018 Inclusion \& Diversity Report which includes statements from senior leadership of the firm such as "we know an inclusive culture leads to true diversity, and I'm not just talking about race and gender but different skillsets, cultural nuances, ethnicity and perspectives any modern organization needs to 
succeed", and "it is not enough to pay lip service to the benefits of a diverse workforce... the payoff is immense" (KPMG 2018). On PwC's website, it states that their "diversity strategy...aims to recognize and embrace all the ways in which people are different, both visibly - for example, in gender and ethnicity - and invisibly, such as cultural or educational background, or personality."10 PwC's 2019 transparency report on audit quality states that "when people from different backgrounds and with different points of view work together, we create the most value - for our clients, our people, and society" (PwC 2019). In these statements is the inherent claim that a culture that emphasizes and values diversity, across multiple dimensions, can lead to improved productivity and outcomes. EY goes as far as to claim that "we believe that diverse and broad perspectives help us conduct higher-quality audits" (EY 2019b).

\section{Literature review}

Schein's (2010) theory of organizational culture acknowledges the influence of firm leaders on culture, noting that leaders are responsible for forming the culture and embedding it throughout the organization (Schein 2010; Kelly and Earley 2009). According to Schein, nonleaders take note of what leaders attend to and control, how they react to crises, how they reward performance, how they model appropriate behavior, how they promote non-leaders through the firm, and how they allocate resources, rewards, and status (Kelly and Earley 2009).

Generally, leaders of a firm establish a culture through the tone they set. A firm's tone is predicated on a firm's policies and procedures, verbal and written communications, and direct actions of upper management (AICPA QC10, 2019; Pickerd, Summers, and Wood 2015). Prior research indicates that a company's tone at the top has important implications for employee behaviors (Bamber et al. 2010; Dyreng et al. 2010). A public accounting firm's tone at the top, as

\footnotetext{
${ }^{10} \mathrm{https://www.pwc.com/us/en/about-us/diversity/pwc-diversity-commitment.html} \mathrm{and} \mathrm{https://www.pwc.co.uk/who-}$ we-are/our-purpose/empowered-people-communities/inclusion.html
} 
exhibited by the partners, represents the embodiment of firm culture and influences the effectiveness of the firm's system of quality control and overall audit quality (Jenkins, Deis, Bedard and Curtis 2008; Bamber and Iyer 2009; Pyzoha, Taylor and Wu 2020). The tone established by firm leaders provides an ethical foundation on which personnel within the firm base their judgments and decisions (COSO 2013). Given the integral influence of an audit firm's tone at the top to the overall system of quality control, standard setters and regulators often focus on firm culture and tone when developing standards and performing periodic firm inspections (IFAC 2007; COSO 2013; PCAOB 2012a, b; 2015).

Despite the importance of culture within accounting firms, "relatively little empirical evidence exists about cultures within firms" (Jenkins et al. 2008, 49). Andiola et al. (2020) note the dearth of research on audit firm diversity and inclusion and audit quality and call for future research on how issues such as age, gender, race, nationality affect firm climates and cultures as well as audit outcomes. Audit firm leaders are expected to establish and uphold an appropriate tone at the top (PCAOB 2012a, b) and leadership climate is engendered not just at the overall firm level but also at lower levels within the firm, including the local office level (Andiola et al. 2020). Office leaders are more likely to have direct communication or acquaintance with the professional staff throughout an office. As such, the tone established by the office leadership is likely even more salient to office personnel than that of the firms' national leaders (Andiola et al. 2020). Therefore, at the construct-level, we focus on the culture and tone in relation to diversity and inclusion within an audit office.

Research examining diversity and audit quality to date has focused on certain individual aspects of engagement team diversity. Cameran et al. (2018) use proprietary data from two Italian Big 4 firms to examine the influence of the gender diversity of the engagement team leaders (i.e., 
managers and partners) on audit quality. A growing stream of research suggests that gender-driven differences in diligence, conservatism, and risk tolerance among female auditors leads to higher quality auditing. This research finds that female audit partners' clients tend to have lower abnormal accruals (Ittonen, Vahamaa, and Vahamaa 2013), are less likely to restate (Li, Qi, Tian, and Zhang 2017) and pay higher audit fees (Hardies et al. 2015; Lee et al. 2019; Burke, Hoitash, and Hoitash 2019). It also finds that female audit partners are more likely to issue a going-concern opinion modification to financially distressed clients (Hardies, Breesch, and Branson 2016). Consistent with these findings, Cameran et al. (2018) find that a larger percentage of women managers and partners on the engagement team is associated with higher earnings quality, suggesting that greater gender diversity among the leaders of the engagement team can lead to higher quality audit engagements.

Cameran et al. (2018) also examine whether a common educational background among engagement team members influences audit quality. While a common technical training can lead to greater efficiency and communication, it could also lead to social conformity in that only a limited set of alternatives are considered when evaluating an issue. Training from a different university can bring diversity of training, thought, and competencies, which could lead to positive outcomes (Campion, Papper, and Medsker 1996). They find that more common educational backgrounds are associated with lower earnings quality, suggesting that greater diversity in technical training can have a positive impact on audit quality at the engagement team-level. In terms of partner ethnicity, Krishnan, Singer, and Zhang (2020) examine and find some evidence that ethnic minority audit partners (of Asian, Black, or Hispanic origin) provide high quality audits.

While these results provide some evidence of the influence of engagement team diversity on audit quality, our examination is not limited to certain isolated aspects of auditor diversity. 
Rather, we focus on the culture and tone of an audit office reflected across a variety of ways in which leaders exhibit and exemplify diversity in thought, background, and perspectives. We argue that a diverse and inclusive culture is likely multi-faceted, manifesting itself in a variety of leadership traits, backgrounds, and experiences. Although the effect of auditor characteristics such as gender, experience, expertise, and age on audit quality has been examined in prior research (primarily among audit partners at the engagement-level), there is no evidence on whether greater variation (i.e., more diversity) along these dimensions among the partners within an audit office affects audit quality across audit office clients, incremental to individual engagement partner characteristics or traits. ${ }^{11}$ We seek to provide empirical evidence on the association of an audit office culture that values diversity and audit quality building on recent research in management and finance that has explored the impact of multi-dimensional measures of diversity within groups on certain outcomes (Anderson et al. 2011; Bernile et al. 2018).

\section{Hypothesis development}

The theoretical foundation motivating our hypothesis focuses on the benefits of a culture embracing diversity on firm performance and judgment and decision-making. Prior research

\footnotetext{
${ }^{11}$ Several studies have examined the association between audit partner experience and expertise and audit quality. With few exceptions (Carey and Simnett 2006), this stream of research largely suggests that greater expertise and experience, both at the client-level and the industry-level lead to increased audit fees and higher quality audit outcomes (Chen, Lin, and Lin 2008; Manry, Mock, and Turner 2008; Zerni 2012; Goodwin and Wu 2014; Cahan and Sun 2015; Chi et al., 2017). In regard to partner education, Cahan and Sun (2015) find that audit partners with graduate degrees are associated with higher audit fees. Burke et al. (2019) find that Big 4 audit partners who attended universities that produce more partners charge higher audit fees. Neither study, however, provides evidence of an association between aspects of partner education and outcome measures of audit quality. Evidence on the effect of partner workloads on audit quality provide mixed results. Sundgren and Svanstrom (2014) find a negative association between a partner's workload and the likelihood of issuing a going-concern report modification. Likewise, Lai, Sasmita, Gul, Foo, and Hutchinson (2017) find that audit partners with more listed clients are associated with larger absolute discretionary accruals, suggesting that partners with heavier workloads provide lower audit quality. On the other hand, Goodwin and Wu (2016) find no reliable association between an auditor's workload and several proxies for audit quality. Results from studies examining the effect of partner age on audit quality suggest a negative association. Sundgren and Svanstrom (2014) find a negative association between auditor age and the propensity to issue a going-concern opinion for a sample of auditors in the Swedish audit environment. Goodwin and $\mathrm{Wu}$ (2016) find a negative association between partner age and audit quality for a sample of Taiwanese auditors.
} 
suggests that a diversity of background, skills, and knowledge among group members enhances problem solving (Bantel and Jackson 1989; Ancona and Caldwell 1992; Pelled, Eisnenhardt, and Xin 1999) and that differences in gender and ethnicity can positively affect decision-making processes by providing more perspectives and expanding the number of alternative decisions considered (Kent and McGrath 1969; Kirchmeyer and Cohen 1992; Watson, Kumar, and Michaelsen 1993). Hence, a culture that values diversity in thought and perspective can reduce emphasis on common knowledge, the likelihood of social conformity, or the isolation of "different" minority group members (Gigone and Hastie 1993). This should facilitate better discussions by encouraging more perspectives and creativity in the decision-making process and moderating extreme alternatives (Kent and McGrath 1969; Kirchmeyer and Cohen 1992; Watson et al. 1993; Bernile et al. 2018).

The arguments above suggest that a culture that values and encourages diversity within an audit office can improve the quality of audits performed. This leads to our hypothesis, stated in the alternative form, as follows:

HYPOTHESIS 1. Engagement partner diversity at the audit office level is associated with higher audit quality among office clientele.

Our hypothesis is not, however, without tension. Some of the prior research supporting the benefits of diversity among groups is often based on variation in individual attributes such as personality, ability, and background and not on other attributes such as age and ethnicity (Altmann and Haythorn 1967; Hoffman 1959; Levy 1964). Likewise, several studies across various disciplines find evidence of greater dysfunctionality and turnover among more diverse groups (Linville and Jones 1980; O'Reilly et al. 1993; Pelled 1996). It is certainly possible that a culture emphasizing greater diversity in thought and perspective could increase frictions between auditors, leading to reduced collaboration or consensus agreement on issues of audit importance, which 
could have negative repercussions on audit judgments and quality. Additionally, it is not clear that audit office culture has an incremental impact to audit quality beyond the individual traits and characteristics of the engagement team auditors. Although certain traits and characteristics of the engagement team auditors can have a direct bearing on the quality of the audit, the influence of audit office culture is perhaps less direct. Finally, it is plausible that the promotion of diversity and inclusion by accounting firms is simply rhetoric to align accounting firms' image with current societal trends. ${ }^{12}$ Thus, it is an empirical question as to whether a culture within audit offices emphasizing the importance of diversity is associated with higher audit quality.

\section{Research methodology}

\section{Office Leadership Diversity Index}

Our construct of interest is an audit office culture that values diversity. We proxy for this construct using the diversity of audit partners within an audit office. Although prior research in the accounting and auditing literatures has generally only considered diversity in certain individual characteristics of auditors, recent literature in management and finance has taken a more holistic, multi-dimensional approach to measuring diversity. ${ }^{13}$ This research tends to focus on two categories of diversity_demographic and cognitive characteristics (e.g., Maznevski 1994; Milliken and Martins 1996). Anderson et al. (2011) measure board heterogeneity along several dimensions including director education, professional experience, board experience, age, gender, and ethnicity. Bernile et al. (2018) also measure board diversity along different dimensions

\footnotetext{
${ }^{12}$ For example, in a recent Forbes article, a managing principal at an HR solutions firm was asked how many companies he thought approach diversity seriously. He stated that "somewhere between 90 and 95 percent of companies just check the box". See https:/www.forbes.com/sites/bonniemarcus/2018/06/29/is-your-company-justpaying-lip-service-to-diversity/\#5c5d30b1263f.

${ }^{13}$ Not all studies examining diversity among management and boards has taken a holistic view of diversity. For example, Carter, Simkins, and Simpson (2003) define diversity based only on race and gender. Minton, Taillard, and Williamson (2014) investigate diversity in financial expertise of board members. Giannetti and Zhao (2019) focus mainly on ethnic diversity of boards of directors.
} 
including education, gender, age, ethnicity, expertise, and board experience. Similar to these studies (Anderson et al. 2011; Bernile et al. 2018), we construct a multi-faceted measure of audit partner diversity at the office level using six audit partner characteristics that include both demographic and cognitive characteristics. Audit partner demographics include gender, age, and ethnicity, while cognitive characteristics include college education, industry expertise, and other client experience. We include diversity in industry expertise and client experience because having more clients or clients from different industries provides partners different backgrounds and perspectives. For example, auditing ten clients in ten different industries provides a more diverse perspective than auditing ten clients in one industry. While more focused industry specialization can be beneficial, it also limits problem solving ability in what is now termed as "wicked" problems (Epstein 2019). Appreciating the unique issues facing a variety of clients brings diversity in experiences and approaches to problem solving and therefore is an important component of measuring diversity of thought and experience in addition to demographic characteristics such as gender or ethnicity.

To construct our diversity measure we first identify engagement partner identities for publicly traded companies using the PCAOB Form AP disclosure. ${ }^{14}$ We downloaded the entire data set of Form AP filings as of August 29, 2019 from the PCAOB website. We categorize audit partners into audit offices based on the audit office listed in the audit report for which they are the lead engagement partner. For each audit office-year, we calculate the fraction of female office audit partners to total audit office partners (FEMALE), the average number of public clients served by office audit partners (MEAN_CLIENTS), the standard deviation of office audit partners' age (STDEV_AGE), and Herfindahl concentration indices for office audit partner ethnicity

\footnotetext{
${ }^{14}$ PCAOB Rule 3211 (available at: https://pcaobus.org/Rules/Pages/Rule-3210-3211.aspx) requires audit partners to be identified in the Form AP disclosure within 35 days of the annual audit report filing.
} 
(HHI_ETHNICITY), institution where the office audit partner received their Bachelor's degree (HHI_BACHELOR), and office audit partner industry expertise $(H H I E X X P R T){ }^{15}$

We capture audit partner gender by manually observing and coding the person's photograph online, unless the gender is unambiguously clear from their first name. We use Audit Analytics data to identify the number of publicly traded clients each audit partner serves in each year of our sample period. We proxy for partner age by using the year the person graduated with their first bachelor's degree. Following Lee et al. (2019), we assume that, on average, people graduate from bachelor's degrees around the age of 22. Following prior research (Ellahie, Tahoun and Tuna 2017; Bernile et al. 2018), we capture audit partner ethnicity using the Onomap classification algorithm, which assigns ethnicity based on first and last name. We calculate HHI_ETHNICITY using ethnic categories of audit partners as provided by Onomap: White/Caucasian, African-American, Hispanic, Asian, and Other. To identify the partners' educational institution, we manually searched for the profile page on a professional networking website using the partner's name and the name of their current audit firm. For all partners we were able to link to a profile, we identify the university where they obtained their bachelor's degree. We construct HHI_BACHELOR using the institutions that granted the bachelor's degrees to each partner. This measure captures the similarity in pedigree from the institution granting the degree. We use Audit Analytics data to construct an audit partner's industry specialization within an MSAyear. We define audit partner industry specialization as the partner with most audit fees within a

\footnotetext{
${ }^{15}$ We have non-missing data for at least 99 percent of partners in an office when calculating FEMALE, MEAN_CLIENTS, HHI_ETHNICITY, HHI_BACHELOR, and HHIEXPERT. However, about 20 percent of audit partners have missing age data in our sample. To mitigate the impact of significant sample attrition, we do not require all partners in an office to have non-missing data to calculate $S T D E V \_A G E$. Our results are robust to dropping offices with under 50 or 75 percent of audit partners with missing age data.
} 
given industry-MSA-year. HHI_EXPERT uses the number of partners that are industry specialist in an industry-metropolitan statistical area (MSA)-year by two digit SIC code.

All variables are normalized to have a mean zero and standard deviation of one to be equally weighted. Our audit office leadership diversity measure is then constructed as follows:

$$
\begin{aligned}
\text { DIVERSITY }= & \operatorname{STDZ}(F E M A L E)+\operatorname{STDZ}(\text { STDEV_AGE })+\operatorname{STDZ}\left(M E A N_{-} C L I E N T S\right) \\
& -\operatorname{STDZ}(\text { HHI_ETHNICITY })-\operatorname{STDZ}(\text { HHI_BACHELOR })-\operatorname{STDZ}(\text { HHI_EXPERT })
\end{aligned}
$$

We add the first three measures (FEMALE, STDEV_AGE, MEAN_CLIENTS) since higher values equate to greater audit partner diversity in an audit office. We subtract the remaining measures since higher values indicate greater concentration and therefore lower partner diversity at the audit office level.

\section{Audit quality measures}

We recognize that no single proxy fully encompasses audit quality. Given the importance of reliable identification, we triangulate the analysis across multiple proxies for audit quality. We proxy for audit quality using measures that capture both inputs into the audit process as well as observable outcome measures of the audit process (DeFond and Zhang 2014). Specifically, we use audit fees to proxy for audit effort, an important input into the audit process. In terms of audit outcome measures, following prior audit quality research, we use misstatements as revealed through subsequent restatements, signed and unsigned measures of discretionary accruals, and a measure of accounting conservatism (see DeFond and Zhang 2014). We include accounting conservatism because auditors have incentives to prefer conservative application of accounting rules to avoid or minimize litigation and reputational damage (DeFond and Subramanyam 1998). We recognize that these outcome measures capture the joint effect of management reporting and the audit process. Although our models control for clients' characteristics to help disentangle the 
quality of the audit from the quality a firm's innate financial reporting quality, we recognize this limitation, which is not unique to this study.

\section{Discretionary accruals}

Our first output-based measure of audit quality is performance-matched discretionary accruals (Kothari. Leone, and Wasley 2005). We estimate discretionary accruals for each firm using the following cross-sectional ordinary least squares regression by two-digit SIC industry and year with at least 10 observations:

$$
T A_{i t} / A_{i t-1}=\beta_{1}\left(1 / A_{i t-1}\right)+\beta_{2}\left(\left(\Delta S_{i t}-\Delta A R_{i t}\right) / A_{i t-1}\right)+\beta_{3}\left(P P E / A_{i t-1}\right)+\varepsilon_{i t}
$$

where TA equals total accruals using the indirect cash flow method (i.e., income before extraordinary items less cash flows from operations); $A$ equals total assets; $\Delta S$ equals the change in total sales from prior year; $\triangle A R$ equals the change in accounts receivable from the prior year; and $P P E$ equals net property, plant, and equipment. We then take the difference between a firm's residual and the residual from a firm with the closest return-on-assets in the same two-digit industry and year providing a performance-matched estimate of discretionary accruals. With this measure, we then estimate the following model:

$$
\text { AB_ACCRUALS } S_{i}=\beta_{0}+\beta_{1} \text { DIVERSITY }+\beta X_{i}+\text { Industry, Audit Firm, MSA, and Year FE }+\varepsilon_{i t}
$$

where DIVERSITY, the variable of interest, is the office leadership diversity index as defined in the previous section. We examine both signed and unsigned measures $A B \_A C C R U A L S$. Signed measures capture the specific direction of potential earnings management while the absolute value captures the magnitude of opportunistic reporting (Reynolds and Francis 2000). The coefficient of interest in this model is $\beta_{1}$, which, consistent with our hypothesis, we expect to be negative, suggesting that a higher level of audit partner diversity within an audit office is associated with higher audit quality. 
Following prior audit office-level research (Bills, Swanquist and Whited 2016, Beck, Francis and Gunn 2018), we control for various audit firm, audit office, and client characteristics, as well as audit firm and MSA fixed effects. ${ }^{16}$ Our audit firm-related control variables include audit firm fixed effects, as well as audit firm changes (AUDITOR_CHG), whether the audit firm has national industry specialization (NATIONAL_LEADER), and the presence of economic incentives in the form of client influence (INFLUENCE), and non-audit fees (NONAUDIT). Audit office-level control variables include office size (OFFICE) and office industry specialization $\left(M S A_{-} L E A D E R\right)$. In addition, we control for the size of the local population in the MSA (LN_POPULATION). To control for geographic variations of labor market supply, we include MSA fixed effects. We control for client characteristics including client size (SIZE), profitability $(R O A)$, valuation $(M B)$ and financial condition (LEVERAGE), ability to manage earnings (CFO, VOLATILITY, and LAG_ACCR), and complexity and risk (SEGMENTS and MW). Finally, we include industry and year fixed effects to control for variation in discretionary accruals across industries and over time. All variables are defined in Appendix A.

\section{Material Misstatements}

Our second output-based measure of audit quality is material misstatements. Prior research suggests that misstated financial statements, as revealed through subsequent restatements, are a clear indication of a lower quality audit (Christensen, Glover, Omer, and Shelley 2016) and exhibit a strong association with PCAOB inspection findings (Aobdia 2019). We define a misstatement equal to one for years in which the annual financial statements are subsequently restated, and zero

\footnotetext{
${ }^{16}$ Since we include audit firm fixed effects and there is no within-firm variation in the Big 4 affiliation, the main effect of Big 4 affiliation is captured in the audit firm fixed effects (Swanquist and Whited 2015; Gunn and Michas 2018). Results are consistent if we include a Big 4 variable and exclude audit firm fixed effects.
} 
otherwise (Francis et al. 2013). Following prior research, we regress misstatements using OLS on our variable of interest, DIVERSITY, and a host of other misstatement determinants as follows: ${ }^{17}$ MISTATEMENT $i t=\beta_{0}+\beta_{1}$ DIVERSITY $+\beta X_{i}+$ Industry, Audit Firm, MSA and Year FE $+\varepsilon_{i t}$

The control variables in the model are consistent with the audit firm, audit office-level, clientlevel, and MSA-level controls and fixed effects included in model (2). The coefficient of interest in this model is $\beta_{1}$, which, consistent with our hypothesis, we expect to be negative. A negative coefficient suggests a lower probability of misstatement when the audit office has greater diversity among office audit partners.

\section{Asymmetric timely loss recognition}

Our third output-based measure of audit quality is timely loss recognition following the model in Basu (1997). This measure captures whether "bad news" is recognized in earnings in a timelier manner than "good news." Given auditors' preference for more conservative financial reporting (DeFond and Subramanyam 1998), a client's more timely loss recognition is likely a product of the audit process and reflects more conservative financial reporting. Consistent with this view, prior research shows that restatement firms exhibit significantly lower levels of conservatism during the period of misstatement relative to non-restatement firms (Ettredge, Huang, and Zhang 2012). We include our DIVERSITY measure in the model with the relevant interactions to test our hypothesis as follows:

$$
\begin{aligned}
& E A R N_{i t}=\beta_{0}+\beta_{1} R E T_{i t}+\beta_{2} N E G_{i t}+\beta_{3} R E T_{i t} * N E G_{i t}+\beta_{4} D I V E R S I T Y_{i t}+\beta_{5} D_{\text {IVERSITY }} * R E T_{i t}+ \\
& \beta_{6} \text { DIVERSITY }_{i t} * N E G_{i t}+\beta_{7} \text { DIVERSITY }_{i t} * N E G_{i t} * \operatorname{RET}_{i t}+\beta_{8} \operatorname{SIZE}_{i, t-1}+\beta_{9} \text { SIZE }_{i, t-1} * \operatorname{RET}_{i t}+ \\
& \beta_{10} S I Z E_{i, t-1} * N E G_{i t}+\beta_{11} S I Z E_{i, t-1} * N E G_{i t} * R E T_{i t}+\beta_{12} M B_{i, t-1}+\beta_{13} M B_{i, t-1} * R E T_{i t}+ \\
& \beta_{14} M B_{i, t-1} * N E G_{i t}+\beta_{15} M B_{i, t-1} * N E G_{i t} * R E T_{i t}+\beta_{16} L_{E V E R A G E_{i, t-1}}+\beta_{17} L_{E V E R A G E}, t-1 *
\end{aligned}
$$

\footnotetext{
${ }^{17}$ We use OLS to estimate the dichotomous variable, MISTATEMENT, due to "complete or quasi- complete separation" problem in the logistic fixed effect model occurs in our data, as some auditors' clients never take a value of 1 in MISTATEMENT and therefore it is impossible to compute the maximum likelihood values. We note that OLS coefficient estimates remain unbiased, especially in large samples, and can be interpreted as usual (Wooldridge 2005, Chap. 7).
} 


$$
R E T_{i t}+\beta_{18} L_{E V E R A G E_{i, t-1}} * N E G_{i t}+\beta_{19} L E V E R A G E_{i, t-1} * N E G_{i t} * R E T_{i t}+
$$

Industry, Audit Firm, MSA, and Year fixed effects $+\varepsilon_{i t}$

where $E A R N$ is earnings divided by the lagged market value of equity; RET is the 12-month cumulative stock return for the fiscal year; and $N E G$ is an indicator variable equal to one if $R E T$ is negative, and zero otherwise. Following prior research (Ettredge et al. 2012; Cunningham, Li, Stein, and Wright 2019), we control for client size (SIZE), expected growth using the market-tobook ratio $(M B)$, and leverage (LEVERAGE). The coefficient of interest in this model is $\beta_{7}$, the coefficient on the interaction of DIVERSITY*NEG*RET, which, consistent with our hypothesis we expect to be positive. A positive coefficient suggests increased accounting conservatism among clients in an audit office with greater audit partner diversity.

\section{Audit fees}

Our input-based measure of audit quality is audit fees. The results of several prior studies suggest that audit fees are highly correlated with audit hours and effort (e.g., see Palmrose 1986; O'Keefe, Simunic, and Stein 1994; Deis and Giroux 1996; Blankley, Hurtt, and MacGregor 2012). Aobdia (2019) finds a significant negative correlation between audit fees and PCAOB inspection deficiencies, which suggests that audit fees reflect audit effort, leading to higher quality audits. Following prior research, we regress the natural $\log$ of audit fees on our variable of interest, DIVERSITY, and a host of other audit fee determinants as follows:

$$
\text { LN_AUDFEES }{ }_{i t}=\beta_{0}+\beta_{1} \text { DIVERSITY }+\beta X_{i}+\text { Industry, Audit Firm, MSA and Year FE }+\varepsilon_{i t}
$$

The control variables in the model are consistent with the audit firm, audit office-level, client-level, and MSA-level controls and fixed effects included in model (2) with the exception of three additional variables (BUSY, FOREIGN, and RECINV) to further control for client complexity based on prior research findings (see Hay, Knechel, and Wong 2006 for a meta-analysis of audit fee research). The coefficient of interest in this model is $\beta$, which, consistent with our hypothesis, 
we expect to be positive. A positive coefficient suggests higher audit effort on client engagements when the audit office has greater audit partner diversity.

\section{Sample and results}

\section{Sample composition and descriptive statistics}

To obtain our sample, we first download all available company-year data from Audit Analytics for fiscal years 2016 through 2018. After merging this data with the Compustat Fundamental Annual database, we are left with 10,410 company-year observations with available data and with assets exceeding \$1 million. We remove 1,220 company-year observations pertaining to audit offices that did not have at least two partners with necessary data for all six dimensions of our diversity measure. We further remove company-year observations in regulated industries (937 in the financial sector and 703 in the utilities sector). We restrict our sample to include only company-year observations within U.S. audit offices of the eight largest accounting firms: PwC, EY, Deloitte, KPMG, Grant Thornton, BDO, RSM, and Crowe. This results in the removal of an additional 1,420 company-year observations leaving a final sample of 6,130 company-year observations. Our sample varies slightly by our audit quality proxy because of specific design considerations for each measure (i.e., the requirement of at least ten observations to model discretionary accruals for each industry-year and necessary returns data to estimate the Basu 1997 model). We outline our sample selection procedures in Table 1.

\section{[INSERT TABLE 1]}

Table 2 presents descriptive statistics of the variables used in our analyses. Our measure of office-level diversity (DIVERSITY) at the company-year level has a mean of 1.64 with a standard deviation of 2.32 , ranging from 0.61 at the $25^{\text {th }}$ percentile of the sample distribution to 2.74 at the $75^{\text {th }}$ percentile. At the audit-office-year level, mean DIVERSITY is 0.45 with a standard deviation 
of 2.77 , ranging from -1.12 at the $25^{\text {th }}$ percentile of the distribution to 2.26 at the $75^{\text {th }}$ percentile. At the office level, the mean proportion of female audit partners is 18 percent. We also find that audit partners within these offices serve 1.4 publicly traded clients on average. The mean level of signed (unsigned) discretionary accruals is $-0.02(0.12)$, consistent with several prior studies that use this audit quality proxy (Ashbaugh, LaFond, and Mayhew 2003; Kothari et al. 2005; Chen et al. 2008). Mean logged audit fees are 14.37 , which translates to an average audit fee of $\$ 1.74$ million. Distributions of other model variables appear reasonable based on prior research.

\section{[INSERT TABLE 2]}

Figure 1 provides a visual overview of the average diversity of office audit partners by state within the U.S. As shown in Figure 1, office audit partner diversity does not appear to concentrate in a particular region in the country. All four geographical regions (North East, Midwest, South, and West) contain at least two states in the top tercile of the distribution of average state-level office audit partner diversity. Figure 2 lists the ten audit-office-years with the highest level of office audit partner diversity (DIVERSITY) and the ten audit-office-years with the lowest level of office audit partner diversity in the sample. Although offices with high diversity appear to concentrate in large cities, the Ernst \& Young Orlando office, which is a fairly small office in terms of professionals and clients, is also included. We also note that certain offices, despite being located in a state with moderate levels of diversity (e.g., Florida, Arizona, and Wisconsin), have very low levels of diversity. This suggests that our measure of office leadership diversity is not simply a reflection of office size or local area diversity.

Table 3 presents the Pearson and Spearman correlations for each of the individual diversity components used to construct our multi-dimensional partner diversity measure. The positive and negative correlations between these individual components and our aggregate diversity measure 
are by construction. We note certain correlations between the individual components. For instance, we find that greater office-level audit partner diversity in educational institution is associated with greater audit partner diversity in gender, age, ethnicity, industry expertise, and the number of publicly traded clients served. Greater diversity in ethnicity is also correlated with greater diversity in gender, age, and the number of publicly traded clients served. These correlations provide some validation that our measure reflects broad diversity among local audit leaders within an audit office as opposed to just a unique or isolated aspect of diversity. However, certain other weak or insignificant correlations between individual components suggest that the aggregation of these components reflects a distinct, multi-faceted measure of audit partner diversity within an audit office.

\section{[INSERT TABLE 3]}

\section{Hypothesis tests}

\section{Discretionary accruals}

Table 4 presents the results of the hypothesis tests using discretionary accruals as a proxy for audit quality. Column (1) presents the results with unsigned discretionary accruals, while columns (2) and (3) present the results after splitting the sample on the sign (negative and positive) of the measure. In columns (1) and (3), we find statistically negative associations between our office-level measure of diversity and both the absolute value and income-increasing discretionary accruals. This suggests that the clients within an audit office with greater audit partner diversity engage in less opportunistic earnings management (both in magnitude and incentivized direction). In column (2), we also find a statistically negative association among firms with negative discretionary accruals, suggesting increased conservatism among this group of firms. These results 
support our hypothesis that greater leadership diversity within an audit office is associated with higher quality audits.

\section{[INSERT TABLE 4]}

\section{Misstatements}

Table 5 presents the results of our second output-based measure of audit quality misstatements. We find a negative and statistically significant coefficient on our variable of interest, DIVERSITY, suggesting that clients of offices with greater audit partner diversity have a lower probability of misstatement. The lack of statistical significance of several of the control variables likely reflects the short time-series of available data and the inclusion of fixed effects. In terms of economic significance, a one standard deviation increase in DIVERSITY (2.31) would decrease misstatement by $-0.924 \%$, which is a $11.6 \%$ decrease in the mean level of misstatement. These results provide evidence consistent with Table 4, suggesting that audit offices that instill a culture of diversity are associated with higher quality audits.

\section{[INSERT TABLE 5]}

\section{Asymmetric timely loss recognition}

Table 6 presents the results of our second output-based measure of audit quality - timely loss recognition following the model in Basu (1997). We find a statistically significant positive coefficient on the interaction between DIVERSITY, RET and NEG, suggesting that clients in offices with greater diversity exhibit a higher likelihood of reporting negative news more timely. To the extent more timely loss recognition reflects more conservative application of accounting principles as a result of the audit process, which aligns with auditor incentives and preferences, these results provide additional corroborating support for our hypothesis of the association between audit office 
leadership diversity and audit quality. The sign and significance of other model variables are consistent with prior research (Ettredge et al. 2012; Cunningham et al. 2019).

[INSERT TABLE 6]

\section{Auditfees}

Table 7 presents the results of our input-based measure of audit quality - audit fees. We note that the model fit, as well as the sign and significance of model variables, are consistent with prior research (Hay et al. 2006). We find a positive and statistically significant coefficient on our variable of interest, DIVERSITY. This result suggests that incremental to other audit fee determinants at the audit firm, audit office, local area, and client-levels, audit fees are

approximately 2.3 percent $\left(=\mathrm{e}^{0.023}-1\right)$ higher for clients audited by offices with greater diversity. Based on the average audit fee in the sample of $\$ 1.74$ million, this represents an additional $\$ 40$ thousand. To the extent audit fees capture audit hours, this result suggests that these offices with greater leadership diversity provide increased audit and monitoring effort. Overall, the results from our output- and input-based measures of audit quality highlight a positive association between audit quality and a local audit office culture valuing diversity.

\section{[INSERT TABLE 7]}

\section{Additional Analyses}

\section{Decomposing Diversity into its Components}

Although our measure of local leadership diversity aligns with the accounting profession's broad view of diversity across multiple dimensions, in additional analyses we decompose our office audit partner diversity measure into its separate components to examine whether any individual component of leadership diversity is driving the observed results. In untabulated analyses, we note that no single diversity component appears to drive the main results for our 
output-based audit quality measures. For discretionary accruals, only three individual components show marginal significance in the predicted direction (greater diversity in the mean number of publicly traded clients, gender and partner industry specialization). However, the sign on the coefficients of several other components (diversity of audit partner age, and ethnicity) are directionally consistent, albeit outside the conventional levels of statistical significance. For our timely loss recognition model, we note that two individual components exhibit the predicted directional association (greater diversity in educational institution and the mean number of publicly traded clients). However, the sign on the coefficients of several other components (diversity of audit partner gender, industry expertise, and ethnicity) are directionally consistent, albeit outside the conventional levels of statistical significance. Thus, in terms of audit quality, there is reason to believe that the aggregation of the various diversity components matters. In the audit fee model, five of the six measures are significant and in the expected direction with the lone insignificant measure being the mean number of publicly traded clients.

To further alleviate the concern that specific individual components of office leadership diversity are driving the observed results, in untabulated analyses, we drop one individual diversity component from our aggregate measure one at a time and re-perform our primary tests. ${ }^{18}$ For all three dependent variables, we find consistent evidence after removing each of the six individual components one at a time. Overall, these analyses suggest that the observed results are not driven by any individual component of our aggregate diversity measure.

\section{Effect of Office Size and Partner Count}

While not necessarily the case, we recognize that greater leadership diversity in an audit office could naturally occur among larger offices with a greater number of partners. In our main

\footnotetext{
${ }^{18}$ Our diversity measure contains six components; therefore, we estimate six separate regressions for each of the three AQ proxies (for total of eighteen regressions).
} 
analysis, we control for office size, local population size within the MSA and include MSA fixed effects. In additional, untabulated analysis, we include an additional control in our models for the number of partners within an office. All results are robust to the inclusion of this control.

To help alleviate the concern that greater office leadership diversity largely reflects the number of partners in an office, we split the sample between large and small offices based on the sample mean number of audit partners in an office each year. We then re-estimate our main tests using these two subsamples. Table 8 , Panel A, presents the results for the discretionary accruals and misstatements tests. For the discretionary accruals tests, the negative and significant association with DIVERSITY is only observed among offices with fewer partners; however, we note that a test of the equality of coefficients on DIVERSITY between the subsamples cannot be rejected. For the misstatement tests, we find consistent results for both subsamples of partner counts and that the coefficients on DIVERSITY between the subsamples are not statistically different. Panel B presents the results for the accounting conservatism tests and the audit fee tests. For both measures, we find consistent results for both subsamples of partner count. When considering the evidence collectively from Table 8 , the effect does not appear to be driven by offices with a greater number of partners.

\section{[INSERT TABLE 8]}

Additionally, we interact our variable of interest, DIVERSITY, with office size (OFFICE) to determine whether audit office leadership diversity is moderated/pronounced by the size of the office in terms of public client audit fees. In untabulated analysis, we find an insignificant coefficient on the interaction in each of our output-based audit quality models. However, in our input-based audit quality model, we find that the interaction is positive and statistically significant, 
suggesting that the influence of audit diversity on audit pricing is particularly pronounced when the audit office is also larger.

\section{Office Leadership Diversity or Individual Engagement Partners?}

Finally, while our measure captures leadership diversity at the office level, we acknowledge the possibility that individual engagement partner characteristics could be correlated with our measure and our proxies for audit quality. We exclude these individual partner characteristics from our main models to avoid sample attrition; however, in additional analyses presented in Table 9, panel A, we include engagement partner age, gender, education, and ethnicity. ${ }^{19}$ Across all four tests, we continue to find consistent results with those in our main analyses, suggesting that the effect of office leadership diversity on audit quality is incremental to these individual engagement partner characteristics. In separate analyses, presented in Table 9, panel $\mathrm{B}$, we include audit partner fixed effects to control for time-invariant unobservable engagement partner characteristics. With the inclusion of these fixed effects we find robust results in the misstatement, conservatism, and audit fees tests. Although we continue to find a negative coefficient on the office leadership diversity variable in the discretionary accruals test, the $p$-value is slightly above conventional levels of statistical significance $(p=0.131){ }^{20}$ Overall, these analyses provide further corroborating support that our office leadership diversity measure largely captures

\footnotetext{
${ }^{19}$ Education controls include whether the partner obtained a graduate degree or graduated from a top accounting program. Top accounting program is obtained from the "Best Undergraduate Accounting Programs" in the most recent U.S. News and World Report rankings following Sunder et al. (2017). These schools include: the University of Texas, Brigham Young University, the University of Illinois, the University of Michigan, the University of Pennsylvania, Indiana University, the University of Notre Dame, the University of Southern California, New York University, the Ohio State University, the University of Florida, and Boston University.

${ }^{20}$ We find a similar result when we incorporate controls for partner characteristics and partner fixed effects in the same models. Results related to accounting conservatism and audit fees are robust. The discretionary accruals test, however, is not statistically significant at conventional levels $(p$-value $=0.21)$.
} 
an association with our audit quality proxies incremental to the effect of individual engagement partner characteristics.

\section{[INSERT TABLE 9]}

\section{Big 4 and Non-Big 4 Audit Firms}

It is unclear whether the diversity and inclusiveness initiatives of the Big 4 audit firms apply equally to smaller audit firms. In untabulated analysis, we split the sample between Big 4 and Non-Big 4 audit firms. We find consistent evidence in the Big 4 sample (coefficients are statistically significant in the expected direction) where the audit firms are more similar in size and diversity initiatives. When examining the Non-Big 4 subsample, results are consistent for the discretionary accruals, misstatement, and audit fees models. For the Basu model, the coefficient is in the expected direction although not significant at conventional levels $(p=0.192)$. Overall, this analysis provides support that our results are not concentrated in either Big 4 or Non-Big 4 clients.

\section{Industry Diversity}

A recent study by Beardsley, Goldman, and Omer (2020) finds a negative association between industry diversity among audit office clients and audit quality. While our study's measure focuses on the diversity of audit leadership characteristics within an office, it is unclear whether client industry diversity could impact our findings. In untabulated analysis, we find that the documented associations in our study are robust to controlling for the Beardsley et al. (2020) audit office client industry diversity measure in all our models. In addition, we interact the industry diversity measure with our leadership diversity measure to determine whether audit partner leadership diversity is moderated/pronounced by the industry diversity of the office. In untabulated analysis, we find an insignificant coefficient on the interaction in each of our input and output-based audit quality models. 


\section{Conclusion}

In this study, we examine whether a culture emphasizing diversity, as embodied by the diversity of offices' audit leaders, influences audit quality. This examination is important given the integral role that firm culture and tone plays in audit firms' overall system of quality control and the significant investment of resources by accounting firms in diversity initiatives related to recruiting, retention, and promotion.

We develop a composite measure of audit office leadership diversity based on six dimensions: gender, age, ethnicity, education, client base, and expertise. We find that greater audit partner diversity within U.S. audit firm offices has an incremental effect on the quality of audits produced by those offices beyond other office level characteristics and a host of other local area, engagement-level, and audit firm-level characteristics. We also find that this effect is incremental to individual engagement partner characteristics or audit partner fixed effects. Specifically, we find that clients in audit offices with more audit partner diversity exhibit lower signed and unsigned discretionary accruals, a lower likelihood of misstatement, more timely loss recognition, and higher audit fees.

Our study provides the first evidence, of which we are aware, of an association between diversity in audit office leadership and audit quality. The results suggest that a culture that values diversity can have an incremental positive influence on audit quality beyond client engagement, audit firm, audit office, or audit partner characteristics. These findings contribute to the growing evidence on the importance of firm culture and tone at the top to firm performance and outcomes (Bamber et al. 2010; Dyreng et al. 2010; Skaife et al. 2013; Brown et al. 2020). These findings have important implications for audit firms' recruiting, retention, and promotion initiatives related to diversity and inclusion and provide empirical evidence for the claims made by accounting firm 
leaders that a culture that embraces and values diversity can have positive externalities for audit quality.

We recognize that our study is subject to limitations. Consistent with much archival audit research, we recognize that audit quality is largely unobservable and that our proxies likely contain measurement error. Despite this limitation, we believe the findings in this study provide growing evidence that underscores the importance of a culture valuing diversity to audit effectiveness. 


\section{References}

Altmann, I., and W. Haythorn. 1967. The effects of social isolation and group composition on performance. Human Relations 20 (4): 313-339.

Ancona, D., and D. Caldwell. 1992. Demography and design: Predictors of new product team performance. Organization Science 3 (3): 321-341.

Anderson, R., D. Reeb, A. Upadhyay, and W. Zhao. 2011. The economics of director heterogeneity. Financial Management 40 (1): 5-38.

Andiola, L. M., D. H. Downey, K. D. Westermann. 2020. Examining Climate and Culture in Audit Firms: Insights, Practice Implications, and Future Research Directions. Auditing: A Journal of Practice and Theory, Forthcoming.

Aobdia, D. 2019. Do practitioner assessments agree with academic proxies for audit quality? Evidence from PCAOB and internal inspections. Journal of Accounting and Economics 67 (1): 144-174.

American Institute of Certified Public Accountants (AICPA). 2019. A Firm's System of Quality Control (QC 10). Available at: https://www.aicpa.org/research/standards/auditattest/downloadabledocuments/qc-00010.pdf

Ashbaugh, H., R. LaFond, and B. W. Mayhew. 2003. Do nonaudit services compromise auditor independence? Further evidence. The Accounting Review 78 (3): 611-639.

Bamber, E. M., and V. Iyer. 2009. The Effect of Auditing Firms' Tone at the Top on Auditors' Job Autonomy, Organizational-professional Conflict, and Job Satisfaction. International Journal of Accounting and Information Management, 17 (2):136-150.

Bamber, L., J. Jiang, and I. Wang. 2010. What's My Style? The Influence of Top Managers on Voluntary Corporate Financial Disclosure. The Accounting Review 85 (4): 1131-162.

Bantel, K., and S. Jackson. 1989. Top management and innovations in banking: Does the composition of the team make a difference? Strategic Management Journal 10 (S1): 107-124.

Beardsley, E., N. C. Goldman, and T. C. Omer. 2020. Audit office industry diversity and audit quality. Working paper, University of Notre Dame, North Carolina State University, and University of Nebraska.

Basu, S. 1997. The conservatism principle and the asymmetric timeliness of earnings. Journal of Accounting and Economics 24 (1): 3-37.

Beck, M. J., J. R. Francis, and J. L. Gunn. 2018. Public company audits and city-specific labor characteristics. Contemporary Accounting Research 35 (1): 394-433. 
Bernile, G., V. Bhagwat, and S. Yonker. 2018. Board diversity, firm risk, and corporate policies. Journal of Financial Economics 127 (3): 588-612.

Bills, K. L., Q. T. Swanquist, and R. L. Whited. 2016. Growing pains: Audit quality and office growth. Contemporary Accounting Research 33 (1): 288-313.

Blankley, A. I., D. N. Hurtt, and J. E. MacGregor. 2012. Abnormal audit fees and restatements. Auditing: A Journal of Practice \& Theory 31 (1): 79-96.

Brown, V., C. E. Earley, and K. Sanderson. 2020. Lost in Translation? An exploratory analysis of auditors' perceptions of the firms' tone at the top. Working Paper. University of WisconsinMilwaukee, Providence College, and Bentley University.

Burke, J. J., R. Hoitash, and U. Hoitash. 2019. Audit partner identification and characteristics: Evidence from US Form AP filings. Auditing: A Journal of Practice and Theory 38 (3): 71-94.

Cahan, S. F., and J. Sun. 2015. The effect of audit experience on audit fees and audit quality. Journal of Accounting, Auditing \& Finance 30 (1): 78-100.

Cameran, M., A. Ditillo, and A. Pettinicchio. 2018. Audit Team Attributes Matter: How Diversity Affects Audit Quality. European Accounting Review 27 (4): 595-621.

Campion, M. A., E. M. Papper, and G. J. Medsker. 1996. Relations between work team characteristics and effectiveness: A replication and extension. Personnel psychology, 49 (2): 429-452.

Carey, P., and R. Simnett. 2006. Audit partner tenure and audit quality. The Accounting Review 81 (3): 653-676.

Carter, D., B. Simkins, and W. Simpson. 2003. Corporate governance, board diversity, and firm value. The Financial Review 38 (1): 33-53.

Chen, C-Y., C-J. Lin, and Y-C. Lin. 2008. Audit partner tenure, audit firm tenure, and discretionary accruals: Dos long auditor tenure impair earnings quality. Contemporary Accounting Research 25 (2): 415-445.

Chi, W., L. A. Myers, T. C. Omer, and H. Xie. 2017. The effects of audit partner pre-client and client-specific experience on audit quality and on perceptions of audit quality. Review of Accounting Studies 22 (1): 361-391.

Christensen, B., S. Glover, T. Omer, and M. Shelley. 2016. Understanding audit quality: Insights from audit professionals and investors. Contemporary Accounting Research 33 (4): 1648-1684.

Committee of Sponsoring Organizations of the Treadway Commission (COSO). 2013. Internal Control-Integrated Framework. New York, NY: COSO. 
Cunningham, L. M., C. Li, S. E. Stein, and N. S. Wright. 2019. What's in a name? Initial evidence of US audit partner identification using difference-in-differences analyses. The Accounting Review 94 (5): 139-163.

Danos, P., J. W. Eichenseher, and D. L. Holt. 1989. Specialized knowledge and its communications in auditing. Contemporary Accounting Research 6 (1): 91-109.

DeFond, M. L., and K. R. Subramanyam. 1998. Auditor changes and discretionary accruals. Journal of Accounting and Economics 25 (1): 35-67.

DeFond, M. L., and J. Zhang. 2014. A review of archival auditing research. Journal of Accounting and Economics 58 (2-3): 275-326.

Deis Jr., D. R., and G. Giroux. 1996. The effect of auditor changes on audit fees, audit hours, and audit quality. Journal of Accounting and Public Policy 15 (1): 55-76.

Deloitte. 2019. Annual Report. Available at: https:/www2.deloitte.com/content/dam/Deloitte/dk/Documents/aboutdeloitte/Deloitte_Annual_report_18_19.pdf

Dyreng, S. D., M. Hanlon, and E. L. Maydew. 2010. The Effects of Executives on Corporate Tax Avoidance. The Accounting Review 85 (4): 1163-89.

Ellahie, A., A. Tahoun, and I. Tuna. 2017. Do common inherited beliefs and values influence CEO pay?. Journal of Accounting and Economics, 64 (2-3), 346-367.

Epstein, D. 2019. Range: Why generalists triumph in a specialized world. Penguin.

Ettredge, M., Y. Huang, and W. Zhang. 2012. Earnings restatements and differential timeliness of accounting conservatism. Journal of Accounting and Economics 53 (3): 489-503.

EY. 2019a. Global review. Available at: https://www.ey.com/en_us/global-review/2019

EY. 2019b. Our commitment to audit quality. Available at https://assets.ey.com/content/dam/eysites/ey-com/en us/topics/assurance/2019-commitment-to-audit-quality-report/our-commitmentto-audit-quality brochure.pdf.

Francis, J. R., and M. D. Yu. 2009. Big 4 office size and audit quality. The Accounting Review 84 (5): 1521-1552.

Francis, J. R., P. N. Michas, and M. D. Yu. 2013. Office size of Big 4 auditors and client restatements. Contemporary Accounting Research 30(4): 1626-1661.

Giannetti, M., and M. Zhao. 2019. Board ancestral diversity and firm performance volatility. Journal of Financial and Quantitative Analysis 54 (3): 1117-1155. 
Gigone, D., and R. Hastie. 1993. The common knowledge effect: Information sharing and group judgment. Journal of Personality and Social Psychology 65 (5): 959-974.

Goodwin, J., and D. Wu. 2014. Is the effect of industry expertise on audit pricing an office-level or a partner-level phenomenon? Review of Accounting Studies 19 (4): 1532-1578.

Goodwin, J., and D. Wu. 2016. What is the relationship between audit partner busyness and audit quality? Contemporary Accounting Research 33 (1): 341-377.

Hardies, K., D. Breesch, and J. Branson. 2015. The female audit fee premium. Auditing: A Journal of Practice \& Theory 34 (4): 171-195.

Hardies, K., D. Breesch, and J. L. Branson. 2016. Do (Fe)Male auditors impair audit quality? Evidence from going-concern opinions. European Accounting Review 25: 7-34.

Hay, D. C., W. R. Knechel, and N. Wong. 2006. Audit fees: A meta-analysis of the effect of supply and demand attributes. Contemporary Accounting Research 23 (1): 141-191.

Hoffman, L. 1959. Homogeneity and member personality and its effect on group problem solving. Journal of Abnormal and Social Psychology 58 (1): 27-32.

Hwang, B. H., and S. Kim. 2009. It pays to have friends. Journal of Financial Economics 93 (1): 138-158.

International Federation of Accountants (IFA). 2007. Tone at the Top and Audit Quality. New York, NY: IFA.

Ittonen, K., E. Vähämaa, and S. Vähämaa. 2013. Female auditors and accruals quality. Accounting Horizons 27 (2): 205-228.

Jenkins, J. G., D. R. Deis, J. C. Bedard and M.B. Curtis. 2008. Accounting Firm Culture and Governance: A Research Synthesis. Behavioral Research in Accounting, 20 (1): 45-74.

Kelly. P. T. and C.E. Earley. 2009. Leadership and Organizational Culture: Lessons Learned from Arthur Andersen. Accounting and the Public Interest, 9: 129-147.

Kent, R., and J. McGrath. 1969. Task and group characteristics as factors affecting group performance. Journal of Experimental Social Psychology 5 (4): 429-440.

Kirchmeyer, C., and A. Cohen. 1992. Multicultural groups: Their performance and reactions with constructive conflict. Group \& Organization Management 17 (2): 153.170.

Kogan, N., and N. Wallach. 1966. Modification of a judgmental style through group interaction. Journal of Personality and Social Psychology 4 (2): 165-174. 
Kothari, S. P., A. J. Leone, and C. E. Wasley. 2005. Performance matched discretionary accrual measures. Journal of Accounting and Economics 39 (1): 163-197.

KPMG. 2018. 2018 KPMG global inclusion \& diversity report. Available at https://assets.kpmg/content/dam/kpmg/xx/pdf/2018/12/the-future-is-inclusive.pdf

KPMG. 2019. Global Review. Available at: https:/home.kpmg/xx/en/home/campaigns/2019/12/global-annual-review.html

Lai, K. M. Y., A. Sasmita, F. A. Gul, Y. B. Foo, and M. Hutchinson. 2017. Busy auditors, ethical behavior, and discretionary accruals quality in Malaysia. Journal of Business Ethics 150 (4): 1187-1198.

Lee, H. S., A. L. Nagy, and A. B. Zimmerman. 2019. Audit partner assignments and audit quality in the United States. The Accounting Review (94) 2: 297-323.

Levy, L. 1964. Group variance and group attractiveness. Journal of Abnormal and Social Psychology 68 (6): 661-664.

Lennox, C. S., and X. Wu. 2018. A review of the archival literature on audit partners. Accounting Horizons 32 (2): 1-35.

Li, L., B. Qi, G. Tian, and G. Zhang. 2017. The contagion effect of low-quality audits at the level of individual auditors. The Accounting Review 92 (1): 137-163.

Linville, P., and E. Jones. 1980. Polarized appraisals of outgroup members. Journal of Personality and Social Psychology 38 (5): 689-703.

Manry, D., T. J. Mock, and J. L. Turner. 2008. Does increased audit partner tenure reduce audit quality? Journal of Accounting, Auditing \& Finance 23 (4): 553-572.

Maznevski, M. L. 1994. Understanding our differences: Performance in decision-making groups with diverse members. Human Relations 47 (5): 531-552.

Milliken, F. J., and L. L. Martins. 1996. Searching for common threads: Understanding the multiple effects of diversity in organizational groups. Academy of Management Review 21 (2): 402-433.

Minton, B., J. Taillard, and R. Williamson. 2014. Financial expertise of the board, risk taking, and performance: Evidence from bank holding companies. Journal of Financial and Quantitative Analysis 49 (2): 351-380.

O’Keefe, T. B., D. A. Simunic, and M. T. Stein. 1994. The production of audit services: Evidence from a major public accounting firm. Journal of Accounting Research 32 (2): 241-261. 
O'Reilly, C., R. Snyder, and J. Boothe. 1993. Effects of executive team demography on organizational change. In G. Huber and W. Glick (Eds.), Organizational change and redesign (pp. 147-175). New York: Oxford University Press.

Palmrose, Z. V. 1986. Audit fees and auditor size: Further evidence. Journal of Accounting Research 24 (1): 97-110.

Pelled, L. 1996. Demographic diversity, conflict, and work group outcomes: An intervening process theory. Organization Science 7 (6): 615-631.

Pelled, L., K. Eisenhardt, and K. Xin. 1999. Demographic diversity in work groups: An empirical assessment of linkages to intragroup conflict and performance. Administrative Science Quarterly 44 (1): 1-28.

Pichai, S., \& Google Inc. 2016. A diverse mix of voices and backgrounds and experiences leads to better discussions, better decisions, and better outcomes for everyone. Google CEO +Sundar Pichai \#wednesdaywisdom [Google+ post]. (May) Retrieved from https://plus.google.com/+LifeatGoogle/posts/QEPntXZx8Mu.

Public Company Accounting Oversight Board (PCAOB). 2012a. Information for Audit 4 Committees About the PCAOB Inspection Process. Release 2012-003. Washington, DC: PCAOB. Available at: http://pcaobus.org/Inspections/Documents/Inspection_Information_for_Audit_Committees.pdf.

PCAOB. 2012b. Staff Audit Practice Alert No. 10 Maintaining and Applying Professional Skepticism in Audits. Washington, D.C.: PCAOB. Available at: https://pcaobus.org/Standards/QandA/12-04-2012_SAPA_10.pdf

PCAOB. 2015. Concept Release on Audit Quality Indicators. PCAOB Release No. 2015-005, July 2015. Washington, DC: PCAOB. Available online: http://pcaobus.org/Rules/Rulemaking/Docket\%20041/Release 2015 005.pdf.

Pickerd, J. S., S. L. Summers, D. A. Wood. 2015. An Examination of How Entry-Level Staff Auditors Respond to Tone at the Top vis-à-vis Tone at the Bottom. Behavioral Research in Accounting 27 (1): 79-98.

PwC. 2019. PwC's Global Annual Review 2019 - Diversity and inclusion. Available at: https://www.pwc.com/gx/en/about-pwc/global-annual-review-2019/downloads/diversity.pdf

Pyzoha, J.S., M. Taylor, Y-J. Wu. 2020. Can auditors pursue firm level goals nonconsciously on audits of complex estimates? An examination of the joint effects of tone at the top and management's specialist. The Accounting Review, Forthcoming.

Reynolds, J. K., and J. R. Francis. 2000. Does size matter? The influence of large clients on office-level auditor reporting decisions. Journal of Accounting and Economics 30 (3): 375-400. 
Sah, R., and J. Stiglitz. 1986. The architecture of economic systems: Hierarchies and polyarchies. The American Economic Review 76 (4): 716-727.

Sah, R., and J. Stiglitz. 1991. The quality of managers in centralized versus decentralized organizations. The Quarterly Journal of Economics 106 (1): 289-295.

Schein, E. H. 2010. Organizational Culture and Leadership. 4th edition. San Francisco, CA: Jossey-Bass, Inc.

Skaife, H. A., D. Veenman, and D. Wangerin. 2013. Internal Control over Financial Reporting and Managerial Rent Extraction: Evidence from the Profitability of Insider Trading. Journal of Accounting and Economics 55 (1): 91-110.

Sundgren, S., and T. Svanström. 2014. Auditor-in-charge characteristics and going-concern reporting. Contemporary Accounting Research 31 (2): 531-550.

Sunder, J., S. Sunder, and J. Zhang. 2017. Pilot CEOs and corporate innovation. Journal of Financial Economics 123 (1): 209-224.

Zerni, M. 2012. Audit partner specialization and audit fees: Some evidence from Sweden. Contemporary Accounting Research 29 (1): 312-340.

Watson, W., K. Kumar, and L. Michaelsen. 1993. Cultural diversity's impact on interaction process and performance: Comparing homogeneous and diverse task groups. Academy of Management Journal 36 (3): 590-602.

Williams, K. Y., and C. A. O'Reilly III. 1998. Demography and diversity in organizations: A review of 40 years of research. Research in Organizational Behavior 20: 77-140.

Wooldridge, J. 2005. Introductory Econometrics: A Modern Approach. Boston, MA: SouthWestern College Publishing. 
Audit Quality Proxies:

AB_ACCRUALS

MISTATEMENT

LN_AUDFEES

EARN

RET

$N E G$

Test Variables:

FEMALE

STDEV_AGE

HHI_ETHNICITY

MEAN_CLIENTS

HHI-BACHELORS

HHI_EXPERT

DIVERSITY

\section{Appendix A Variable Definitions}

Abnormal (or discretionary) accruals based on the modified Jones model using a cross-sectional regression for each industry and year with at least 10 observations. Following Cunningham et al. (2019), we take the difference of each company's residual with the residual from a company with the closest ROA in the same industry and year.

Indicator variable set equal to 1 if the financial statements are misstated (as revealed through a subsequent restatement announcement), and 0 otherwise.

The natural logarithm of audit fees.

Earnings before extraordinary items (IB) divided by the lagged market value of equity (PRCC_F*CSHO).

Annual buy and hold return estimated for the fiscal year. Return data is obtained from CRSP. Indicator variable equal to 1 if RET is negative, and 0 otherwise.

Number of female partners divided by total office partners. Standard deviation of the ages of the partners. We proxy for partner age by using the year the person graduated with their first bachelor's degree.

Herfindahl index of the number of partners in each firm-year that are classified in categories by ethnicity, as defined in Onomap. Onomap's ethnic categories are Asian, AfricanAmerican, Caucasian, Hispanic, and Other.

For each firm-year, the mean number of other Partner clients Herfindahl index of the number of partners in each firm-year that are classified in categories by their bachelor's granting institution.

Herfindahl index of the number of partners in each firm-year that are classified as having industry expertise.

For each auditor-office-year, this index is computed as (Female partner ratio) + HHI age + Mean Clients - HHI bachelors - HHI Ethnicity - HHI expert). Each individual measure is standardized to have a mean 0 and standard deviation of 1 . 
Auditor Control Variables:

AUDITOR_CHG

INFLUENCE

NONAUDIT

MSA_LEADER

NATIONAL_LEADER

OFFICE

LN_POPULATION

$A G E$

GENDER

GRADUATE_DEGREE

TOP_ACCOUNTING_PROGRAM

ETHNICITY

Client Control Variables:

$B U S Y$

$\mathrm{CFO}$

FOREIGN

$L A G \_A C C R$

LEVERAGE
Indicator variable equal to 1 if the one if the company changes auditors in the current year, and 0 otherwise.

Clients audit fees as a percentage of office audit fees The natural $\log$ of $1+$ Non audit service fees

Indicator variable equal to one if an office is the number one auditor in terms of aggregated client audit fees in an industry within that MSA in a specific fiscal year, and zero otherwise

Indicator variable equal to one if an auditor is the number one auditor in an industry in terms of aggregated audit fees in a specific fiscal year, and zero otherwise

Measure of office size based on the number of SEC registrants audited by each auditor-office-year.

Natural log of the 2010 census population of the MSA in which the auditor-office is located in a year.

Year the person graduated with their first bachelor's degree plus an additional 22 years (Ellahie, Tahoun and Tuna 2017; Bernile et al. 2018).

Indicator variable equal to one if the audit engagement partner is a female, and zero otherwise.

Indicator variable equal to one if the audit engagement partner obtained a graduate degree, and zero otherwise. Indicator variable equal to one if the audit engagement partner obtained a graduate degree or graduated from a top accounting program. Top accounting program is obtained from the "Best Undergraduate Accounting Programs" in the most recent U.S. News and World Report rankings following Sunder et al. (2017).

Categorical variable equal to one of the following ethnic categories: White/Caucasian, African-American, Hispanic, Asian, and Other.

Indicator variable equal to 1 when fiscal year end is in December, and 0 otherwise.

Cash flow from operations (OANCF) divided by total assets (AT).

Indicator variable equal to 1 if the company has foreign sales in the Compustat Segments file, and 0 otherwise.

Total current accruals (IB - (OANCF - XIDOC)) in the prior year divided by total assets (AT) at the end of year $\mathrm{t}-2$.

Total debt (DLC + DLTT) divided by total assets (AT). 
Client Control Variables:

$M B$

$M W$

RECINV

$R O A$

SEGMENTS

SIZE

VOLATILITY
Market value of assets (AT + $\left.\left(\mathrm{PRCC} \mathrm{F}^{*} \mathrm{CSHO}\right)-\mathrm{CEQ}\right)$ divided by book value of assets (AT).

Indicator variable equal to 1 if the company or the auditor disclosed a material weakness under SOX 404a/404b (data from Audit Analytics), and 0 otherwise.

The ratio of accounts receivable (RECT) and inventories (INVT) to total assets (AT).

Earnings before extraordinary items (IB) divided by total assets (AT).

Natural logarithm of 1 plus the number of business segments in the Compustat Segments file.

Natural logarithm of total assets (AT).

Standard deviation of CFO over the prior three years ( $\mathrm{t}-2$ to t). 
Figure 1 Office leadership diversity by state

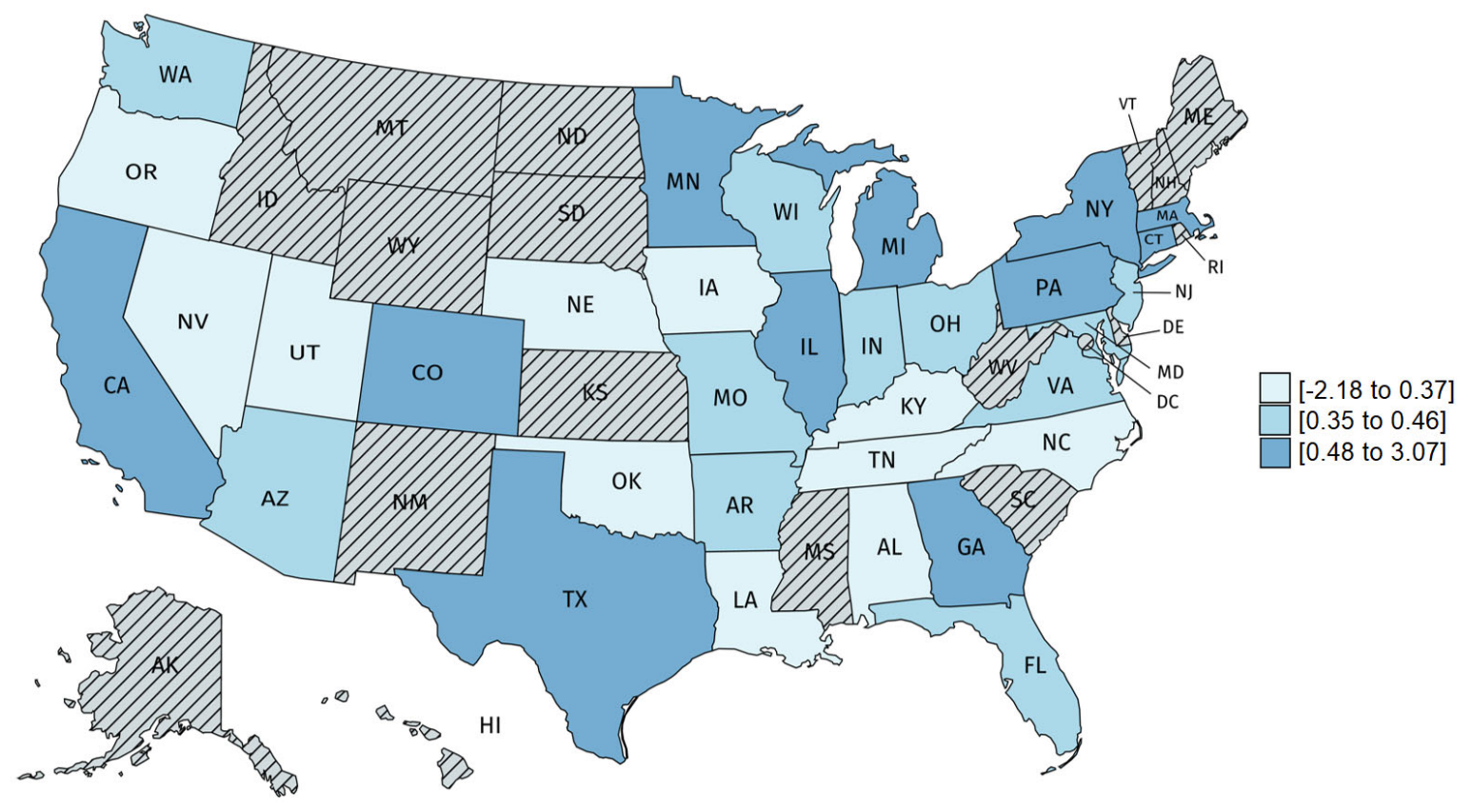

Note: The figure above displays average value of the office leadership diversity in each state. Averages are based on the office-year observations over the entire sample period. States with fewer than 3 observations are set to missing. 
Figure 2 Top/bottom 10 diversity offices

\begin{tabular}{lccc} 
Year & \multicolumn{1}{c}{ Top 10 } & & \\
2017 & City & State & Auditor \\
2016 & NEW YORK & NY & GRANT THORNTON LLP \\
2018 & NEW YORK & NY & GRANT THORNTON LLP \\
2018 & NEW YORK & NY & GRANT THORNTON LLP \\
2017 & CHICAGO & IL & GRANT THORNTON LLP \\
2018 & CHICAGO & IL & GRANT THORNTON LLP \\
2017 & CHICAGO & IL & DELOITTE \& TOUCHE LLP \\
2016 & CHICAGO & IL & DELOITTE \& TOUCHE LLP \\
2018 & CHICAGO & IL & GRANT THORNTON LLP \\
2017 & BOSTON & MA & DELOITTE \& TOUCHE LLP \\
& ORLANDO & FL & ERNST \& YOUNG LLP
\end{tabular}

Year
2017
2016
2017
2018
2017
2017
2017
2018
2016
2016

Bottom 10

$\begin{array}{ccc}\text { City } & \text { State } & \text { Auditor } \\ \text { OKLAHOMA CITY } & \text { OK } & \text { ERNST \& YOUNG LLP } \\ \text { NORFOLK } & \text { VA } & \text { KPMG LLP } \\ \text { DES MOINES } & \text { IA } & \text { RSM US LLP } \\ \text { MILWAUKEE } & \text { WI } & \text { RSM US LLP } \\ \text { SHREVEPORT } & \text { LA } & \text { KPMG LLP } \\ \text { MIAMI } & \text { FL } & \text { DELOITTE \& TOUCHE LLP } \\ \text { MIAMI } & \text { FL } & \text { GRANT THORNTON LLP } \\ \text { CHARLOTTE } & \text { NC } & \text { KPMG LLP } \\ \text { PHOENIX } & \text { AZ } & \text { RSM US LLP } \\ \text { ROCHESTER } & \text { NY } & \text { DELOITTE \& TOUCHE LLP }\end{array}$

Note: The figure above shows the ten audit-office-years with the highest level of audit office leadership diversity (DIVERSITY) and the ten audit-office-years with the lowest level of diversity in the sample. 
TABLE 1

Sample construction

Audit Analytics observations from 2016 to 2018

24,648

Less: Missing financial and audit data

Less: Observations with no Diversity data

Less: Financial sector (SIC codes 60-69)

Less: Regulated industries (SIC codes 44-49)

Less: Observations without Top 8 Auditor

Total observations for the Misstatement and Fees Models

6,130

Total observations for the Accruals Models

6,026

Total observations for the Basu (1997) Model

5,671 
TABLE 2

Summary statistics

\begin{tabular}{|c|c|c|c|c|c|c|}
\hline Variable & $\mathbf{N}$ & Mean & STD & P25 & P50 & P75 \\
\hline$A B \_A C C R U A L S$ (absolute value) & 6026 & 0.12 & 0.15 & 0.03 & 0.07 & 0.14 \\
\hline$A C C R U A L S$ & 6026 & -0.02 & 0.18 & -0.08 & -0.01 & 0.05 \\
\hline MISTATEMENT & 6130 & 0.08 & 0.36 & 0.00 & 0.00 & 0.00 \\
\hline LN AUDFEES & 6130 & 14.37 & 1.04 & 13.64 & 14.35 & 15.02 \\
\hline RET & 5671 & -0.01 & 0.44 & -0.28 & -0.05 & 0.18 \\
\hline EARN & 6130 & -0.1 & 0.44 & -0.07 & 0.02 & 0.05 \\
\hline$N E G$ & 6130 & 0.59 & 0.49 & 0.00 & 1.00 & 1.00 \\
\hline DIVERSITY & 6130 & 1.64 & 2.32 & 0.61 & 1.83 & 2.74 \\
\hline AUDITOR_CHG & 6130 & 0.04 & 0.20 & 0.00 & 0.00 & 0.00 \\
\hline BUSY & 6130 & 0.84 & 0.37 & 1.00 & 1.00 & 1.00 \\
\hline NONAUDIT & 6130 & 10.47 & 4.58 & 9.95 & 11.93 & 13.32 \\
\hline INFLUENCE & 6130 & 0.08 & 0.12 & 0.01 & 0.04 & 0.10 \\
\hline LN_POPULATION & 6130 & 15.19 & 0.95 & 14.56 & 15.33 & 15.6 \\
\hline CFO & 6130 & 0.01 & 0.26 & 0.01 & 0.08 & 0.13 \\
\hline VOLATILITY & 6130 & 0.08 & 0.13 & 0.02 & 0.03 & 0.07 \\
\hline FOREIGN & 6130 & 0.63 & 0.48 & 0.00 & 1.00 & 1.00 \\
\hline RECINV & 6130 & 0.22 & 0.18 & 0.07 & 0.18 & 0.32 \\
\hline$L A G \_A C C R$ & 6130 & -0.10 & 0.16 & -0.12 & -0.07 & -0.03 \\
\hline LEVERAGE & 6130 & 0.27 & 0.25 & 0.06 & 0.24 & 0.40 \\
\hline$M B$ & 6130 & 3.81 & 9.13 & 1.29 & 2.42 & 4.52 \\
\hline$M S A \_L E A D E R$ & 6130 & 0.37 & 0.48 & 0.00 & 0.00 & 1.00 \\
\hline$M W$ & 6130 & 0.07 & 0.26 & 0.00 & 0.00 & 0.00 \\
\hline NATIONAL_LEADER & 6130 & 0.27 & 0.44 & 0.00 & 0.00 & 1.00 \\
\hline SEGMENTS & 6130 & 2.49 & 1.83 & 1.00 & 1.00 & 4.00 \\
\hline OFFICE & 6130 & 48.54 & 61.72 & 10.00 & 24.00 & 52.00 \\
\hline$R O A$ & 6130 & -0.06 & 0.27 & -0.08 & 0.02 & 0.07 \\
\hline SIZE & 6130 & 6.97 & 1.92 & 5.69 & 7.03 & 8.27 \\
\hline \multicolumn{7}{|l|}{ All Office-Years } \\
\hline DIVERSITY & 771 & 0.45 & 2.77 & -1.12 & 0.85 & 2.26 \\
\hline FEMALE & 771 & 0.18 & 0.18 & 0.00 & 0.17 & 0.29 \\
\hline$S T D E V \_A G E$ & 771 & 5.07 & 2.87 & 3.54 & 5.29 & 6.63 \\
\hline HHI_EDUCATION & 771 & 0.30 & 0.21 & 0.14 & 0.25 & 0.50 \\
\hline HHI_ETHNICITY & 771 & 0.80 & 0.20 & 0.63 & 0.81 & 1.00 \\
\hline HHI_EXPERT & 771 & 0.79 & 0.20 & 0.60 & 0.76 & 1.00 \\
\hline MEAN_CLIENTS & 771 & 1.42 & 3.53 & 0.33 & 0.71 & 1.33 \\
\hline
\end{tabular}

Variables are defined in the Appendix. 
TABLE 3

Pearson/Spearman correlations for diversity index components

1 - DIVERSITY

2 - FEMALE

3 - STDEV $A G E$

\begin{tabular}{ccccccc}
\hline 1 & 2 & 3 & 4 & 5 & 6 & 7 \\
\hline & $\mathbf{0 . 4 8}$ & $\mathbf{0 . 4 5}$ & $\mathbf{( 0 . 6 6 )}$ & $\mathbf{( 0 . 5 4 )}$ & $\mathbf{( 0 . 4 2 )}$ & $\mathbf{0 . 3 4}$ \\
$\mathbf{0 . 3 9}$ & & 0.03 & $\mathbf{( 0 . 2 0 )}$ & $\mathbf{( 0 . 0 9 )}$ & 0.02 & $\mathbf{0 . 1 0}$ \\
$\mathbf{0 . 4 6}$ & 0.01 & & $\mathbf{( 0 . 3 0 )}$ & $\mathbf{( 0 . 0 9 )}$ & $(0.03)$ & $\mathbf{0 . 1 5}$ \\
$(\mathbf{0 . 6 7 )}$ & $\mathbf{( 0 . 0 8 )}$ & $\mathbf{( 0 . 3 0 )}$ & & $\mathbf{0 . 2 4}$ & $\mathbf{0 . 1 5}$ & $\mathbf{( 0 . 3 2 )}$ \\
$(\mathbf{0 . 5 2})$ & $(0.06)$ & $(0.06)$ & $\mathbf{0 . 2 3}$ & & 0.02 & $\mathbf{( 0 . 1 1 )}$ \\
$\mathbf{( 0 . 4 0 )}$ & 0.04 & $(0.03)$ & $\mathbf{0 . 2 0}$ & 0.02 & & 0.03 \\
$\mathbf{0 . 4 8}$ & 0.04 & $\mathbf{0 . 0 9}$ & $\mathbf{( 0 . 1 7 )}$ & $\mathbf{( 0 . 1 6 )}$ & $\mathbf{0 . 1 0}$ & \\
\hline
\end{tabular}

4 - HHI_EDUCATION

5 - HHI_ETHNICITY

6 - HHI_EXPERT

0.48

$0.09 \quad(0.17) \quad(0.16)$

$\mathbf{0 . 1 0}$

Note: Pearson correlation coefficients are presented below the diagonal and Spearman correlation coefficients are presented above the diagonal. Coefficients are bolded if significant at the $5 \%$ level. 
TABLE 4

Office audit leader diversity and discretionary accruals

\begin{tabular}{|c|c|c|c|}
\hline & $\begin{array}{c}\mathrm{DV}=A B \_A C C R U A L S \\
\text { (absolute value) }\end{array}$ & $\begin{array}{c}\mathrm{DV}= \\
A B \_A C C R U A L S \\
\text { (income-decreasing } \\
\text { only) } \\
\end{array}$ & $\begin{array}{c}\mathrm{DV}= \\
A B \_A C C R U A L S \\
\text { (income- } \\
\text { increasing only) }\end{array}$ \\
\hline & $(1)$ & $(2)$ & $(3)$ \\
\hline \multirow[t]{2}{*}{$\overline{D I V E R S I T Y}$} & $-0.003 * * *$ & $-0.003 * *$ & $-0.003 * *$ \\
\hline & {$[-2.994]$} & {$[-2.187]$} & {$[-2.021]$} \\
\hline \multicolumn{4}{|c|}{ Audit firm-related control variables } \\
\hline AUDITOR_CHG & 0.013 & 0.007 & 0.022 \\
\hline NATIONAL_LEADER & 0.002 & 0.006 & -0.004 \\
\hline INFLUENCE & -0.010 & -0.004 & -0.024 \\
\hline NONAUDIT & 0.001 & 0.001 & 0.000 \\
\hline OFFICE & $0.000 * *$ & $0.000 *$ & 0.000 \\
\hline$M S A \_L E A D E R$ & $0.007 * *$ & $0.008 *$ & 0.004 \\
\hline$L N \_\bar{P} O P U L A T I O N$ & -0.006 & -0.014 & $0.010^{*}$ \\
\hline \multicolumn{4}{|c|}{ Client-related control variables } \\
\hline SIZE & $-0.006 * * *$ & $-0.004 *$ & $-0.009 * * *$ \\
\hline$R O A$ & $-0.146 * * *$ & $-0.220 * * *$ & 0.023 \\
\hline$M B$ & $0.001 * *$ & $0.001 * *$ & 0.000 \\
\hline LEVERAGE & 0.005 & -0.011 & $0.035^{* *}$ \\
\hline $\mathrm{CFO}$ & $0.046^{*}$ & $0.115^{* * *}$ & $-0.100 * *$ \\
\hline VOLATILITY & $0.193 * * *$ & $0.234 * * *$ & $0.166^{* * *}$ \\
\hline$L A G \_A C C R$ & 0.005 & 0.002 & $0.029^{*}$ \\
\hline SEGMENTS & -0.001 & -0.001 & 0.001 \\
\hline$M W$ & $0.013^{*}$ & 0.016 & -0.002 \\
\hline Intercept & 0.100 & 0.205 & -0.113 \\
\hline Observations & 6026 & 3831 & 2195 \\
\hline Adjusted R2 & 0.239 & 0.362 & 0.350 \\
\hline Ind FE & Yes & Yes & Yes \\
\hline Audit Firm FE & Yes & Yes & Yes \\
\hline MSA FE & Yes & Yes & Yes \\
\hline Year FE & Yes & Yes & Yes \\
\hline
\end{tabular}

Note: Column 1 presents results from OLS regressions the absolute performance-matched discretionary accruals (DA) from a cross-sectional modified Jones model. Column 2 (Column 3) presents a subsample of only negative (positive) performance-matched discretionary accruals (DA). Robust standard errors are clustered by firm. t-statistics are in brackets under the coefficient estimates. ${ }^{*}, * *$, and $* * *$ denote statistical significance at the 10,5 and 1\% levels. The significance of the coefficients for the audit office leadership diversity proxy is based on a one-tailed test given the directional prediction in our hypothesis, while the significance of coefficients on the control variables is based on a two-tailed test. Appendix A provides the variable definitions. 
TABLE 5

Office audit leader diversity and misstatements

\begin{tabular}{|c|c|}
\hline & $\mathrm{DV}=\mathrm{MISTATEMENT}$ \\
\hline & (1) \\
\hline \multirow[t]{2}{*}{ DIVERSITY } & $-0.004 * *$ \\
\hline & {$[-2.190]$} \\
\hline \multicolumn{2}{|c|}{ Audit firm-related control variables } \\
\hline AUDITOR_CHG & 0.026 \\
\hline NATIONAL_LEADER & 0.004 \\
\hline INFLUENCE & 0.036 \\
\hline NONAUDIT & 0.000 \\
\hline OFFICE & 0.000 \\
\hline$M S A \_L E A D E R$ & 0.004 \\
\hline LN_POPULATION & $-0.034 * *$ \\
\hline \multicolumn{2}{|c|}{ Client-related control variables } \\
\hline$S I Z E$ & 0.002 \\
\hline$R O A$ & 0.025 \\
\hline$M B$ & -0.000 \\
\hline LEVERAGE & 0.006 \\
\hline $\mathrm{CFO}$ & -0.020 \\
\hline VOLATILITY & -0.000 \\
\hline$L A G \_A C C R$ & -0.004 \\
\hline SEGMENTS & 0.003 \\
\hline$M W$ & $0.159 * * *$ \\
\hline Intercept & $0.505 * *$ \\
\hline Observations & 6130 \\
\hline Adjusted R2 & 0.084 \\
\hline Ind $\mathrm{FE}$ & Yes \\
\hline Audit Firm FE & Yes \\
\hline MSA FE & Yes \\
\hline Year FE & Yes \\
\hline
\end{tabular}

Note: Column 1 presents the OLS regression results from the misstatement test.

Robust standard errors are clustered by firm. t-statistics are in brackets under the coefficient estimates. ${ }^{*}, * *$, and $* * *$ denote statistical significance at the 10,5 and $1 \%$ levels. The significance of the coefficients for the audit office leadership diversity proxy is based on a one-tailed test given the directional prediction in our hypothesis, while the significance of coefficients on the control variables is based on a two-tailed test. Appendix A provides the variable definitions. 
TABLE 6

Office audit leader diversity and asymmetric timely loss recognition

\begin{tabular}{|c|c|}
\hline & $\mathrm{DV}=E A R N$ \\
\hline & $(1)$ \\
\hline$R E T$ & 0.038 \\
\hline & {$[0.979]$} \\
\hline$N E G$ & $0.413 * * *$ \\
\hline & {$[7.465]$} \\
\hline$R E T^{*} N E G$ & $2.057 * * *$ \\
\hline & {$[9.576]$} \\
\hline DIVERSITY & -0.000 \\
\hline & {$[-0.075]$} \\
\hline DIVERSITY*RET & -0.005 \\
\hline & {$[-1.023]$} \\
\hline$D I V E R S I T Y * R E T * N E G$ & $0.091 * *$ \\
\hline & {$[2.211]$} \\
\hline SIZE & $0.019 * * *$ \\
\hline$S I Z E^{*} R E T$ & -0.006 \\
\hline$S I Z E^{*} N E G$ & $-0.044 * * *$ \\
\hline$S I Z E^{*} R E T^{*} N E G$ & $-0.189 * * *$ \\
\hline$M B$ & -0.000 \\
\hline$M B^{*} R E T$ & 0.000 \\
\hline$M B * N E G$ & -0.001 \\
\hline$M B * R E T * N E G$ & $-0.012 * *$ \\
\hline LEVERAGE & -0.058 \\
\hline LEVERAGE*RET & 0.022 \\
\hline$L E V E R A G E^{*} N E G$ & $0.242 * * *$ \\
\hline$L E V E R A G E^{*} R E T^{*} N E G$ & $0.887 * * *$ \\
\hline Intercept & $-0.165 * * *$ \\
\hline Observations & 5671 \\
\hline Adjusted R2 & 0.331 \\
\hline Ind FE & Yes \\
\hline Audit Firm FE & Yes \\
\hline MSA FE & Yes \\
\hline Year FE & Yes \\
\hline
\end{tabular}

Note: This table presents the OLS regression results for audit quality proxied by the Basu (1997) model for asymmetric timely loss recognition. SIZE, MB, and LEVERAGE represent the lagged variables at the end of year $\mathrm{t}-1$. For brevity, coefficients on industry and year fixed effects are not reported. Robust standard errors clustered by client firm are included in parentheses. $* * * * *$, and $*$ represent significance at the $0.01,0.05$, and 0.10 levels, respectively. The significance of the coefficients for the audit office leadership diversity proxy is based on a one-tailed test given the directional prediction in our hypothesis, while the significance of coefficients on the control variables is based on a two-tailed test. Appendix A provides the variable definitions. 
TABLE 7

Office audit practice leader diversity and audit fees

\begin{tabular}{|c|c|}
\hline & $\begin{array}{c}\mathrm{DV}= \\
L N \_A U D F E E S\end{array}$ \\
\hline & (1) \\
\hline \multirow[t]{2}{*}{ DIVERSITY } & $0.023 * * *$ \\
\hline & {$[5.996]$} \\
\hline \multicolumn{2}{|c|}{ Audit firm-related control variables } \\
\hline AUDITOR_CHG & $-0.165 * * *$ \\
\hline NATIONAL_LEADER & 0.006 \\
\hline INFLUENCE & $1.607 * * *$ \\
\hline NONAUDIT & $0.009 * * *$ \\
\hline OFFICE & -0.000 \\
\hline MSA_LEADER & $0.105 * * *$ \\
\hline LN_POPULATION & $-0.134 *$ \\
\hline \multicolumn{2}{|c|}{ Client-related control variables } \\
\hline SIZE & $0.379 * * *$ \\
\hline$R O A$ & $-0.263 * * *$ \\
\hline$M B$ & $0.001 * *$ \\
\hline LEVERAGE & $0.142 * * *$ \\
\hline $\mathrm{CFO}$ & -0.060 \\
\hline VOLATILITY & $0.161 * *$ \\
\hline$L A G \_A C C R$ & 0.002 \\
\hline SEGMENTS & $0.056 * * *$ \\
\hline$M W$ & $0.249 * * *$ \\
\hline BUSY & 0.032 \\
\hline FOREIGN & $0.177 * * *$ \\
\hline RECINV & $0.680 * * *$ \\
\hline Intercept & $12.432 * * *$ \\
\hline Observations & 6130 \\
\hline Adjusted R2 & 0.835 \\
\hline Ind $\mathrm{FE}$ & Yes \\
\hline Audit Firm FE & Yes \\
\hline MSA FE & Yes \\
\hline Year FE & Yes \\
\hline
\end{tabular}

Note: This table presents the OLS regression results from estimating the natural log of audit fees using OLS. Robust standard errors are clustered by firm. t-statistics are in brackets under the coefficient estimates. *, $* *$, and $* * *$ denote statistical significance at the 10,5 and $1 \%$ levels, respectively. The significance of the coefficients for the audit office leadership diversity proxy is based on a one-tailed test given the directional prediction in our hypothesis, while the significance of coefficients on the control variables is based on a two-tailed test. Appendix A provides the variable definitions. 
TABLE 8

Panel A: Office leadership diversity and partner count

\begin{tabular}{|c|c|c|c|c|c|c|}
\hline & \multicolumn{2}{|c|}{$\mathrm{DV}=A B \_A C C R U A L S$ (absolute value) } & \multicolumn{4}{|c|}{$\mathrm{DV}=M I S T A T E M E N T$} \\
\hline & $(1)$ & $(2)$ & $(3)$ & & $(4)$ & \\
\hline DIVERSITY & $\begin{array}{c}-0.001 \\
{[-0.260]}\end{array}$ & $\begin{array}{c}-\mathbf{0 . 0 0 4} \\
{[-3.509]}\end{array}$ & $\begin{array}{c}-0.008 \\
{[-2.390]}\end{array}$ & $* * *$ & $\begin{array}{c}-0.004 \\
{[-1.293]}\end{array}$ & $*$ \\
\hline Subsample & Large & Small & Large & & Small & \\
\hline Observations & 2846 & 3180 & 2880 & & 3250 & \\
\hline Adjusted R2 & 0.239 & 0.242 & 0.239 & & 0.242 & \\
\hline Controls & Yes & Yes & Yes & & Yes & \\
\hline Ind FE & Yes & Yes & Yes & & Yes & \\
\hline Auditor FE & Yes & Yes & Yes & & Yes & \\
\hline MSA FE & Yes & Yes & Yes & & Yes & \\
\hline Year FE & Yes & Yes & Yes & & Yes & \\
\hline \multicolumn{6}{|l|}{$\chi 2$ Test of Coeff. Diff. } & \\
\hline between Large and Small Offices & \multicolumn{2}{|c|}{1.54} & \multicolumn{3}{|c|}{0.34} & \\
\hline
\end{tabular}

Note: This table presents the Large Offices (Large) versus Small Office (Small) subsample OLS regression results for the association between office leadership diversity and audit quality. We split the sample by yearly mean partner count within the office. Robust standard errors are clustered by firm. t-statistics are in brackets under the coefficient estimates. $* * *$, and $* * *$ denote statistical significance at the 10,5 and $1 \%$ levels, respectively. The significance of the coefficients for the audit office leadership diversity proxy is based on a one-tailed test given the directional prediction in our hypothesis. Appendix A provides the variable definitions. 
TABLE 8

Panel B: Office leadership diversity and partner count

\begin{tabular}{|c|c|c|c|c|c|c|c|c|}
\hline & \multicolumn{4}{|c|}{$\mathrm{DV}=E A R N$} & \multicolumn{4}{|c|}{$\mathrm{DV}=L N \_A U D F E E S$} \\
\hline & (1) & & $(2)$ & & $(3)$ & & (4) & \\
\hline DIVERSITY & & & & & $\begin{array}{c}\mathbf{0 . 0 2 1} \\
{[2.500]}\end{array}$ & $* * *$ & $\begin{array}{c}\mathbf{0 . 0 2 8} \\
{[5.987]}\end{array}$ & $* * *$ \\
\hline DIVERSITY*RET ${ }^{*} N E G$ & $\begin{array}{c}0.164 \\
{[1.589]}\end{array}$ & $*$ & $\begin{array}{c}0.084 \\
{[1.698]}\end{array}$ & $* *$ & & & & \\
\hline Subsample & Large & & Small & & Large & & Small & \\
\hline Observations & 2798 & & 2873 & & 2880 & & 3250 & \\
\hline Adjusted R2 & 0.39 & & 0.294 & & 0.834 & & 0.864 & \\
\hline Controls & Yes & & Yes & & Yes & & Yes & \\
\hline Ind FE & Yes & & Yes & & Yes & & Yes & \\
\hline Auditor FE & Yes & & Yes & & Yes & & Yes & \\
\hline MSA FE & Yes & & Yes & & Yes & & Yes & \\
\hline Year FE & Yes & & Yes & & Yes & & Yes & \\
\hline \multicolumn{9}{|l|}{$\chi 2$ Test of Coeff. Diff. } \\
\hline between Large and Small Offices & \multicolumn{3}{|c|}{0.51} & & \multicolumn{3}{|c|}{0.57} & \\
\hline
\end{tabular}


TABLE 9

Panel A: Diversity and partner characteristics

\begin{tabular}{|c|c|c|c|c|c|c|c|c|}
\hline & $\begin{array}{l}\mathrm{DV}=A B \\
\quad(\text { absolu }\end{array}$ & $\begin{array}{l}R U A L S \\
\text { lue) }\end{array}$ & $\begin{array}{r}\text { DV } \\
\text { MISTATE }\end{array}$ & & $\mathrm{DV}=E$ & & $\begin{array}{r}\text { DV } \\
L N \_A U\end{array}$ & $E E S$ \\
\hline & (1) & & (2) & & (3) & & (4) & \\
\hline DIVERSITY & -0.003 & $* * *$ & -0.004 & * & & & 0.021 & $* * *$ \\
\hline & {$[-2.688]$} & & {$[-1.495]$} & & & & {$[5.020]$} & \\
\hline DIVERSITY*RET ${ }^{*} N E G$ & & & & & 0.104 & $* *$ & & \\
\hline & & & & & [2.156] & & & \\
\hline$A G E$ & 0.001 & & -0.001 & & 0.001 & & 0.004 & $* *$ \\
\hline & [1.259] & & {$[-0.706]$} & & {$[0.572]$} & & [2.478] & \\
\hline GENDER & -0.003 & & 0.017 & & 0.009 & & 0.03 & \\
\hline & {$[-0.502]$} & & {$[1.397]$} & & {$[0.616]$} & & [1.403] & \\
\hline GRADUATE_DEGREE & 0.001 & & -0.008 & & 0.027 & $*$ & -0.019 & \\
\hline & {$[0.114]$} & & {$[-0.777]$} & & {$[1.800]$} & & {$[-0.908]$} & \\
\hline TOP_ACCOUNTING_PROGRAM & -0.005 & & -0.017 & & 0.003 & & -0.034 & \\
\hline & {$[-0.972]$} & & {$[-1.501]$} & & {$[0.195]$} & & {$[-1.476]$} & \\
\hline ETHNICITY & 0.001 & & 0.005 & & 0.006 & & 0.011 & \\
\hline & {$[0.415]$} & & {$[0.824]$} & & [0.944] & & [1.101] & \\
\hline Observations & 4385 & & 4462 & & 4120 & & 4462 & \\
\hline Adjusted R2 & 0.240 & & 0.084 & & 0.325 & & 0.836 & \\
\hline Controls & Yes & & Yes & & Yes & & Yes & \\
\hline Ind, Auditor, MSA, and Year FE & Yes & & Yes & & Yes & & Yes & \\
\hline Partner FE & No & & No & & No & & No & \\
\hline
\end{tabular}


TABLE 9 (Continued)

Panel B: Diversity and partner fixed effects

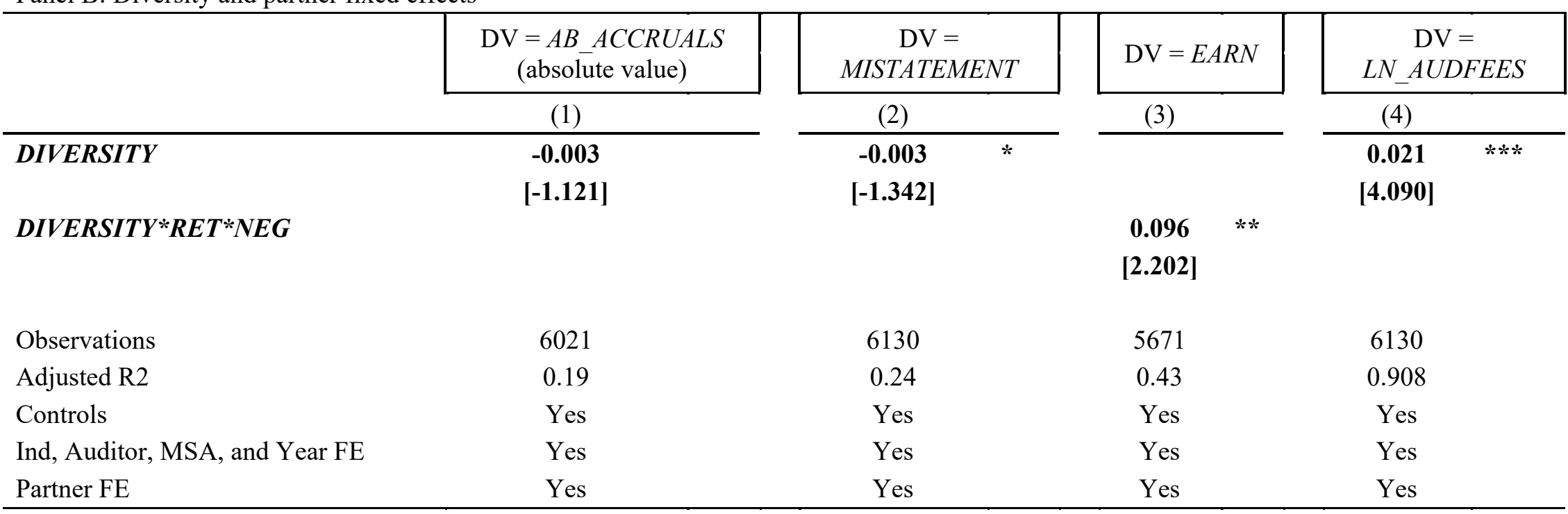

Note: This table presents our primary analyses with the inclusion of partner fixed effects. Robust standard errors are clustered by firm. $\mathrm{t}$ statistics are in brackets under the coefficient estimates. *,**, and $* * *$ denote statistical significance at the 10,5 and $1 \%$ levels, respectively. The significance of the coefficients for the audit office leadership diversity proxy is based on a one-tailed test given the directional prediction in our hypothesis. Appendix A provides the variable definitions. 